\title{
Salivary proteins of Phloeomyzus passerinii, a plant-manipulating aphid, and their impact on early gene responses of susceptible and resistant poplar genotypes
}

\author{
Luis Portillo Lemus ${ }^{\mathrm{a}, \mathrm{b}, 1}$, Jessy Tricard ${ }^{\mathrm{a}, \mathrm{b}, 1}$, Jérôme Duclercq ${ }^{\mathrm{b}}$, Quentin Coulette ${ }^{\mathrm{b}}$, David Giron ${ }^{\mathrm{c}}$, \\ Christophe Hano ${ }^{\mathrm{a}}$, Elisabeth Huguet ${ }^{\mathrm{c}}$, Frédéric Lamblin ${ }^{\mathrm{a}}$, Anas Cherqui ${ }^{\mathrm{b}, 2}$, Aurélien Sallé, ${ }^{\mathrm{a}, 2, *}$ \\ ${ }^{\text {a }}$ Laboratoire de Biologie des Ligneux et des Grandes Cultures, INRA, Université d'Orléans, 45067, Orléans, France \\ ${ }^{\mathrm{b}}$ Ecologie et Dynamique des Systèmes Anthropisés, EDYSAN UMR CNRS-UPJV 7058, Université de Picardie Jules Verne, Amiens, France \\ ${ }^{\mathrm{c}}$ Institut de Recherche sur la Biologie de l'Insecte, UMR 7261, CNRS/Université François-Rabelais de Tours, Tours, France
}

\section{A R T I C L E I N F O}

\section{Keywords:}

Effector

Effector-triggered susceptibility

Myzus persicae

Plant-insect interaction

Populus

Resistance

Auxin

Cytokinin

\begin{abstract}
A B S T R A C T
Successful plant colonization by parasites requires the circumvention of host defenses, and sometimes a reprogramming of host metabolism, mediated by effector molecules delivered into the host. Using transcriptomic and enzymatic approaches, we characterized salivary glands and saliva of Phloeomyzus passerinii, an aphid exhibiting an atypical feeding strategy. Plant responses to salivary extracts of $P$. passerinii and Myzus persicae were assessed with poplar protoplasts of a susceptible and a resistant genotype, and in a heterologous Arabidopsis system. We predict that $P$. passerinii secretes a highly peculiar saliva containing effectors potentially interfering with host defenses, biotic stress signaling and plant metabolism, notably phosphatidylinositol phosphate kinases which seemed specific to $P$. passerinii. Gene expression profiles indicated that salivary extracts of $M$. persicae markedly affected host defenses and biotic stress signaling, while salivary extracts of $P$. passerinii induced only weak responses. The effector-triggered susceptibility was characterized by downregulations of genes involved in cytokinin signaling and auxin homeostasis. This suggests that $P$. passerinii induces an intracellular accumulation of auxin in susceptible host genotypes, which is supported by histochemical assays in Arabidopsis. This might in turn affect biotic stress signaling and contribute to host tissue manipulation by the aphid.
\end{abstract}

\section{Introduction}

In nature, plants engage in multiple interactions with a variety of organisms, resulting in either beneficial or detrimental impacts on plant performance. These interplays are mediated by effectors delivered into the host-plant, either in the apoplast or within plant cells [1,2]. Effectors can be defined as molecules secreted by plant-associated organisms that alter host cell structure and function, positively or negatively depending on the partners involved [1]. This can be achieved through a direct modification of host molecules, or of their activity, by effectors with enzymatic or binding activities, or a modification of host gene expression by effectors with a nucleic acid binding activity [3].

Within the frame of host-parasite interactions, effectors have evolved to target various host functions and key processes. They primarily aim at suppressing plant immunity $[1,3]$. For instance, parasites can target and inactivate plant second messengers involved in stress signaling such as $\mathrm{Ca}^{2+}$, reactive oxygen species (ROS) and extracellular ATP with cation-binding effectors, peroxiredoxins and apyrases, respectively $[4,5]$. In some situations, effectors can also alter plant development, and promote the manipulation of plant resources by parasites $[1,3,6]$. For example, several pathogens secrete effectors which induce the production of sugar efflux transporters and hijack host sugars for their own nutrition [7]. Similar reconfiguration of host plant metabolism and tissues, to turn them into optimal substrates for development and fitness, have also been reported in plant pests e.g. $[6,8,9]$. Successful interactions among parasite effectors and their targets lead to an effector-triggered susceptibility [3]. Nonetheless, resistant plant genotypes have evolved receptors, mostly with nucleotide-binding leucine-rich repeat (NB-LRR), that specifically interact with parasite effectors to induce an effector-triggered immunity [10].

\footnotetext{
* Corresponding author.

E-mail address: aurelien.salle@univ-orleans.fr (A. Sallé).

${ }^{1}$ These authors should be considered joint first author.

2 These authors should be considered joint senior author.
} 
Microbial pathogen effectors have been extensively studied e.g. [11, 12]. Comparatively, effectors of insect herbivores and their impact on host plants have received only a limited attention until recently $[13,14]$. Evidence indicates that both effector-triggered susceptibility and immunity also occur in plant-insect interactions e.g. [15,16]. Consequently, as for pathogens, a deep mechanistic understanding of effector action, i.e. an identification of effectors involved in the interplay and of their targets in host-plants, would be necessary to develop a sustainable management of agricultural and forestry pests, based on resistant plant genotypes [17].

The woolly poplar aphid, Phloeomyzus passerinii Sign., is a major pest of poplar plantations in the Mediterranean Basin, the Near East and France [18]. This aphid does not feed on sap but in the cortical parenchyma of its host-trees, where it induces a reaction tissue presumably acting as a physiological sink, draining nutrients from surrounding tissues [18-20]. During aphid outbreaks, when poplar trunks are covered with aphid colonies, the accumulation of reaction tissues dramatically affects host allocations of non-structural carbohydrates and nitrogen compounds, and infested mature trees can die rapidly, within a few months $[18,21]$. Such outbreaks only occur in stands of susceptible poplar genotypes. Detailed histochemical investigations during early stages of infestation have unraveled that tissues affected by the unusually damaging probing activity of $P$. passerinii in these susceptible genotypes exhibit weak defense reactions, with limited lignification and accumulation of phenolic compounds [19,20]. During later stages, a reaction tissue differentiate in the cortical parenchyma, characterized by an intense cell multiplication and hypertrophy, an accumulation of free and protein-bound amino acids, and an absence of both vacuolar phenolic compounds and starch granules [20,22]. The differentiation of this reaction tissue improves both aphid performance and feeding behavior [23]. Conversely, in resistant poplar genotypes, an intense lignification and a marked accumulation of phenolic compounds occur readily after the onset of probing, blocking further differentiation of reaction tissues and preventing aphid colonization [18,20]. It is therefore likely that $P$. passerinii induces either an effector-triggered susceptibility in susceptible poplar genotypes, allowing a beneficial manipulation of host tissue for the aphid, or a rapid and intense immunity response in resistant poplar genotypes preventing aphid nutrition. Indepth functional approaches would allow to unravel the molecular mechanisms that contribute to either the success or the failure of this pest's establishment on its host-plant, which could ultimately help to improve poplar breeding programmes.

We hypothesize (i) that since it has a peculiar feeding strategy for an aphid [23], and it can hijack and reconfigure the metabolism of its host plant to improve its nutritional value, $P$. passerinii should possess a rich and atypical repertoire of salivary effectors compared to other sapfeeding aphids. Considering that susceptible hosts implement weak defense reactions when infested, we further hypothesize (ii) that salivary effectors successfully alter biotic stress signaling and / or defense molecules in these host genotypes to induce an effector-triggered susceptibility. Alternatively, in resistant hosts, the effector-triggered immunity should lead to a marked upregulation of defense-related genes. Finally, since it can manipulate host metabolism and anatomy, our last hypothesis (iii) is that some of salivary effectors of $P$. passerinii can target genes involved in the cell-division cycle and / or induce the disruption or diversion of auxin and/or cytokinin-dependent pathways, which are important regulators of plant growth, differentiation and defense [6,24].

More specifically, our first objective was to characterize with transcriptomic and enzymatic approaches the salivary gland encoded proteins and saliva, respectively, of $P$. passerinii. Our second objective was to assess in vivo, with a RT-qPCR approach, early responses of poplar genes belonging to different metabolic and signaling pathways using protoplasts exposed to aphid saliva. Protoplasts were used to simulate a host cellular response to salivary effectors of aphids. Our last objective was to investigate the impact of salivary extracts on specific gene expression in planta, in a heterologous Arabidopsis system.

For all these steps comparative approaches were used. The predicted salivary gland encoded proteins of $P$. passerinii were compared with those of a sap-feeding aphid, Myzus persicae (Sulzer) [25,26], in order to identify proteins common to both aphid species as well as proteins specific to $P$. passerinii. To get insight into how $P$. passerinii affects host immune system and metabolism during both an effector-triggered susceptibility and an immune response, the impact of salivary extracts on gene expression were assessed with poplar genotypes either susceptible or resistant to $P$. passerinii. To compare with non-host interactions, the protoplasts of these poplar genotypes were also exposed to salivary extracts of $M$. persicae, which do not feed on poplar.

\section{Materials and methods}

\subsection{Plant and insect material}

Two aphid species were considered in our study: $P$. passerinii, our model species, and the green peach aphid, M. persicae. Both aphid species are Aphididae, but belong to different subfamilies (P. passerinii is the only member of the Phloeomyzinae while $M$. persicae is an Aphidinae), which diverged at $137 \mathrm{Ma}$ [27]. Compared to P. passerinii, M. persicae exhibit a quite different feeding strategy since it is a sapfeeder, which host range does not include poplars, and preliminary establishment attempts confirmed that it cannot settle and develop on poplars (data not shown). Firstly, considering both species allowed to compare secretomes from two aphids with distinct feeding strategies, and to test whether the atypical feeding strategy of $P$. passerinii results in an unusual saliva composition, particularly enriched with potential effectors. Secondly, it allowed to compare an interaction with a specialist parasite to a non-host species interaction, i.e. an interaction that would act as a positive control for defense reaction.

All individuals of $P$. passerinii used either for transcriptomic analyses of salivary glands or saliva collection originated from the same monoclonal colony established from an apterous parthenogenetic female, collected in 2013 in Brézé (France, 47 16'36" N 0 06'84" W, WGS-84). The colony was maintained in the laboratory on potted stem cuttings of $\mathrm{I}-214$, a Populus $x$ canadensis Moench. genotype, under $20 \pm 1{ }^{\circ} \mathrm{C}$, $70 \pm 10 \%$ relative humidity and $16 / 8 \mathrm{~h}$ light/dark cycles. Individuals of $M$. persicae originated from a monoclonal colony established from an apterous parthenogenetic female collected in 1999 on a potato plant in Loos-en-Gohelle (France, $50^{\circ} 27^{\prime} 44^{\prime \prime} \mathrm{N} 2^{\circ} 46^{\prime} 45^{\prime \prime}$ E, WGS-84). The colony was maintained under the same controlled conditions as $P$. passerinii, on turnips (Vilmorin).

Two $P$. $x$ canadensis genotypes commonly planted in France, I-214 and Koster, were used for the experiments. Populus $x$ canadensis is a host species for $P$. passerinii. However, both genotypes differ in their susceptibility to $P$. passerinii. I-214 is highly susceptible. The aphid shows high performance when fed with this genotype, and can induce its reaction tissue within its cortical parenchyma. Conversely P. passerinii cannot settle on Koster, and consequently induce a reaction tissue. This genotype is consequently considered to be highly resistant [18]. Considering these two poplar genotypes allowed to investigate interactions with $P$. passerinii leading either to an effector-triggered susceptibility, with the susceptible I-214 genotype, or to resistance, with the resistant Koster genotype. Populus $x$ canadensis is not a host species for M. persicae and non-host species interactions between this aphid and both poplar genotypes were consequently expected. Stem cuttings (ca. $25 \mathrm{~cm}$ long, $2 \mathrm{~cm}$ diameter) were provided by the experimental nursery of Guéméné-Penfao (Office National des Forêts, France). They were collected in the autumn of 2016, and kept at $2{ }^{\circ} \mathrm{C}$, in dry conditions until use. In January 2017, the stem-cuttings were removed from storage and planted in $0.4 \mathrm{~L}$ pots, filled with a sterile sand-compost (50:50) mixture (Klasmann substrate 4 no. 267). The cuttings were then transferred to a growth chamber $\left(20 \pm 1{ }^{\circ} \mathrm{C}, 70 \pm 10 \%\right.$ relative humidity, $16 / 8 \mathrm{~h}$ light/ dark photoperiod, $2.65 \mathrm{kLx}$, and watered three times a week). Leaves 
were then used for protoplast production (see 2.3.3).

For in planta functional validation of the effects of salivary proteins, two transgenic lines of Arabidopsis thaliana (L.) Heynh. were used. The transgenic line pIAA2:GUS [28] was used to assess the auxin response, with its auxin-responsive promoter, while the cytokinin response was evaluated with pARR16: GUS, with its cytokinin-responsive promoter [29]. Seeds were sterilized with chloral gas, sown in Petri dishes on 0.8 $\%(\mathrm{w} / \mathrm{v})$ agar with $1 \%(\mathrm{w} / \mathrm{v})$ sucrose-containing 0.5 Murashige and Skoog medium (MS), stored for 2 days at $4{ }^{\circ} \mathrm{C}$, and grown on vertically oriented plates in growth chambers under a $16 / 8 \mathrm{~h}$ light/dark photoperiod at $18{ }^{\circ} \mathrm{C}$.

\subsection{Salivary transcriptome}

\subsubsection{Sample collection, RNA isolation and de novo transcriptome assembly}

About 500 adults of apterous parthenogenetic $P$. passerinii aphids, collected directly on their host-plant, were dissected to collect pairs of salivary glands. Total RNA was extracted using the GeneJET RNA Purification kit (Thermo Fischer Scientific), according to manufacturer's instructions. RNA was DNase treated using RNase-Free DNase Set (Qiagen). RNA concentration was measured using the Qubit ${ }^{\circledR}$ RNA Assay Kit (Life Technologies) and a Qubit ${ }^{\circledR} 2.0$ Fluorometer (Invitrogen). Construction of cDNA-library and sequencing were performed by Eurofins ${ }^{\circledR}$ Genomics using a MiSeq v3 Reagent Kit (600 Cycles PE, Illumina, USA) and a MiSeq sequencer (Illumina), with 12.5 $\mu \mathrm{g}$ of total RNA. For the de novo transcriptome assembly, 15,453,942 pair-ended reads were sequenced and assembled using Velvet (v1.2.10; [30]) and Oases (v0.2.8 [31];) software tools (table S1). A multi-kmer approach was applied. Separate assemblies with different kmer lengths were conducted and the individual assemblies were merged to a final assembly. Kmer lengths of 69, 89, 109 and 129 were used. The separate assemblies were merged following the filter1-CD-HIT-EST procedure proposed in Yang \& Smith [32]. A completeness assessment was performed using gVolante (v1.2.1 [33];) with the pipeline BUSCO v2/v3 and the reference dataset Arthropoda (table S1). This Transcriptome Shotgun Assembly project was deposited at DDBJ/EMBL/GenBank under the accession GHDF00000000. The version described in this paper is the first version, GHDF01000000.

\subsubsection{Annotation, secreted proteins detection and identification}

To perform comparisons with $M$. persicae the transcriptome of this aphid was retrieved on NCBI (http://www.ncbi.nlm.nih.gov/genbank/, accession numbers: DW010205 - DW015017, EC387039 - EC390992, EE570018 - EE572264, EE260858 - EE265165, ES444641 - ES444705, ES217505 - ES226848, and ES449829 - ES451794). Salivary transcriptomes were annotated using the pipeline described in figure S1. Transcripts were first translated into amino acid sequences using Prodigal (v2.5; [34]). We then used the SignalP 4.0 Server (v4.1) to predict the presence of signal peptides and cleavage sites in the amino acid sequences [35]. To predict transmembrane domains, we submitted each amino acid sequence with a signal peptide to the TMHMM Server (v. 2.0 [36];). Putative proteins with a signal peptide and no transmembrane domain were considered to be potential secreted proteins. The sequences of complete ORFs without signal peptide were analyzed again with SecretomeP (v2.0 [37]). To remove mitochondrial proteins with a signal peptide, which are not secreted in the saliva, sequences were analyzed with TargetP (v1.1 [38]). Likewise, to remove proteins of the endoplasmic reticulum with a signal peptide, sequences were analyzed with PS-scan (Prosite pattern: PS00014), and with PredGPI [39] for glycosylphosphatidylinositol-anchor signals.

The remaining proteins were first mapped against the non-redundant protein sequences (nr) using Blastp (v2.3.0, NCBI, accessed on $03 / 30 / 2016$ ), with an E-value cutoff at $1^{\mathrm{e}-3}$. Protein domains were annotated with Blast2Go (v3.3; [40]), and InterProScan (v5.30-69 [41]). Whenever possible, protein sequences were assigned to Gene ontology (GO) terms with an E-value cutoff at $1^{\mathrm{e}-6}$, enzyme codes (EC) and KEGG pathways.

OrthoVenn (http://aegilops.wheat.ucdavis.edu/OrthoVenn; [42]) was used to identify orthologous proteins within and between salivary transcriptomes of the two aphids. Intraspecific orthologous proteins are first grouped into clusters, which are then compared between species. Each cluster was annotated with the Uniprot database (http://www. uniprot.org; [43]) and the nr peptide sequence database (NCBI, accessed on $03 / 30 / 2016$ ).

To detect proteins orthologous to salivary effectors of aphids, protein sequences of known aphid effectors, i.e. C002, ACE1, ACE2, ACYPI39568, ACYPI00346, MpC002, Mp1, Mp2, Mp42, Mp55, Me10, Me23 [44-46], were compared to the salivary transcriptome of $P$. passerinii with Blastp (E-value $\leq 1^{\mathrm{e}-3}$ ).

\subsection{Functional validation assays}

\subsubsection{Aphid saliva collection}

Aphids secrete two types of saliva within their host-plants, liquid and solid saliva [4]. The solid saliva is secreted during probing. It hardens rapidly and forms a solid sheath encasing aphid stylets within the host-plant, while the liquid saliva is secreted within cells and sieve tubes [4]. Both types of saliva contain effectors e.g. [4, 47], and were collected in our experiments. Because of the particular trophic substrates of $M$. persicae and $P$. passerinii (i.e. sap and cortical tissues, respectively), a special protocol was used for each species. The saliva of $P$. passerinii was collected after incubation of 30-40 individuals of $2 \mathrm{nd}$ and 3rd instars aphids on sachets of Parafilm(C) membranes containing an artificial diet [48]. The artificial diets were constituted by a disc of 0.5 $\%(\mathrm{w} / \mathrm{v})$ agar completed with $150 \mu \mathrm{L}$ of $15 \%(\mathrm{w} / \mathrm{v})$ sucrose. The saliva of $M$. persicae was collected after incubation of 30-40 individuals, of 3rd and 4th instars, on artificial diet containing $120 \mu \mathrm{L}$ of a $15 \%(\mathrm{w} / \mathrm{v})$ sucrose as previously described by Cherqui \& Tjallingii [48]. Aphids were deposited in a feeding chamber during $24 \mathrm{~h}$ at $20{ }^{\circ} \mathrm{C}, 60 \pm 1 \%$ relative humidity and a $16 / 8 \mathrm{~h}$ light/dark period with $2.65 \mathrm{kLx}$. Feeding chambers containing the artificial diets, incubated in the absence of aphids, were used as control samples.

For $P$. passerinii, after $24 \mathrm{~h}$ aphid salivation, artificial diet discs were collected and transferred into $100 \mu \mathrm{L}$ of TE buffer (10 mM Tris, $1 \mathrm{mM}$ EDTA, pH 8). The salivary proteins were released from the artificial diet according to Yang et al. [49], with slight modifications. The tubes containing artificial diet discs were frozen in liquid nitrogen for $1 \mathrm{~min}$, immediately thawed at $70{ }^{\circ} \mathrm{C}$ for $3 \mathrm{~min}$ and then centrifuged at $11,000 \mathrm{x}$ $g$ for $20 \mathrm{~s}$. To discard the excess of agar, salivary extracts were centrifuged in Sartorius tubes with filters of $0.22 \mu \mathrm{m}$. The supernatant containing salivary proteins of $P$. passerinii were collected, pooled and then stored at $-20^{\circ} \mathrm{C}$. For M. persicae, after $24 \mathrm{~h}$ salivation, aphid saliva was collected according to Harmel et al. [25]. The artificial diet is collected containing soluble saliva. The solid saliva was collected during the rinsing of each lower Parafilm membrane with TE buffer containing $0.1 \%(\mathrm{w} / \mathrm{v})$ of Tween $20(\mathrm{TE} / \mathrm{Tween})$. The extracts were centrifuged at $10,000 \mathrm{x} g$ for $15 \mathrm{~min}$. The salivary proteins in the pellet were collected, pooled with the soluble saliva and then stored at $-20^{\circ} \mathrm{C}$.

The sample containing protein saliva extracts were concentrated using $2 \mathrm{~mL}$ Vivaspin $\Subset$ tube Sartorius with $3 \mathrm{kDa}$ cut-off. The tubes were then centrifuged at $5000 \times \mathrm{g}$ for $70-120 \mathrm{~min}$ according to sample volumes, and proteins adhering to membranes were recovered by $100 \mu \mathrm{L}$ of TE/Tween buffer. Control samples were prepared with artificial diets from feeding chambers without aphids. The protein quantification was performed by measuring absorbance at $280 \mathrm{~nm}$ with the NanoDrop(C) 1000 (ThermoScientific).

\subsubsection{Enzyme activities}

Several enzyme substrates were added to the previously described artificial diets with or without agarose to detect enzymatic activities present in saliva excreted from the aphid. To visualize proteins in the 
salivary sheaths, the lower Parafilm $($ membranes were stained by adding a drop of $0.01 \%(\mathrm{w} / \mathrm{v})$ Coomassie blue in $10 \%(\mathrm{v} / \mathrm{v})$ glycerol for $2 \mathrm{~h}$. Dihydroxyphenylalanine (DOPA), $0.1 \%(\mathrm{w} / \mathrm{v})$ was added to identify phenoloxidase activity (PO; catechol oxidase, EC 1.10.3.1). The enzymatic product, melanin, should stain salivary sheaths and halos around the sheaths. To detect peroxidase (EC 1.11.1.7) activity, artificial diets were immersed for some minutes in $0.1 \%(\mathrm{w} / \mathrm{v})$ diaminobenzidine (DAB, Sigma) in $50 \mathrm{mM}$ Tris (pH 7.5) containing $0.1 \%(\mathrm{v} / \mathrm{v})$ $\mathrm{H}_{2} \mathrm{O}_{2}$ (Sigma). The enzymatic product should induce reddish staining of salivary sheaths and halos. For identification of pectinase activity, 0.1 $\%(\mathrm{w} / \mathrm{v})$ of pectin (Sigma) was added to the medium. After exposure to aphids, the gel was transferred for $3 \mathrm{~h}$ into a Petri dish containing 50 $\mathrm{mM}$ citrate-phosphate buffer, at $\mathrm{pH} 5.0$ to detect pectin (methyl) esterase (PME, EC 3.1.1.11) and at $\mathrm{pH} 6.4$ to detect polygalacturonase (PG, EC 3.1.1.15). The gel was then stained with a solution of $0.01 \%$ $(\mathrm{w} / \mathrm{v})$ ruthenium red (Sigma) for $1 \mathrm{~h}$, and then washed several times with distilled water. At $\mathrm{pH}$ 6.4, red halos around the salivary sheaths indicate PME activity, while non-staining halos at $\mathrm{pH} 5$ in the pink pectin indicate PG activity. Finally, for proteinase activity (EC 3.4.99), $0.5 \%(\mathrm{w} / \mathrm{v})$ of gelatin (Sigma) was added to the medium. After exposure to aphids, the medium was incubated overnight in a solution of $50 \mathrm{mM}$ Tris (pH 8) containing $100 \mathrm{mM} \mathrm{NaCl}$ and $10 \mathrm{mM} \mathrm{CaCl}_{2}$, then stained with Coomassie blue. An absence of blue staining shows proteinase activity. All observations of proteins and enzymatic activities were performed by light microscopy (Axioplan 2, Zeiss, Jena, Germany).

\subsubsection{Poplar protoplast preparations and treatments}

We wanted to assess early poplar gene responses to aphid saliva, as interactions between elicitors and effectors of herbivores and plant receptors occur readily after the onset of probing or feeding [50]. Once deposited on their plant material, adults and nymphs of $P$. passerinii can wait for several hours before probing and delivering saliva into host tissues, inject probably a varying amount of saliva and presumably affect a limited number of host cells [19,20]. Therefore, we used protoplasts as plant material in order to (i) have a sufficient amount of plant material exposed to treatments for the RT-qPCR experiments, (ii) have an identical exposure duration and intensity to salivary extracts among biological replicates, and (iii) avoid the effects of physical stimuli exerted by aphid stylets on plant cells. Mesophyll protoplasts of the two poplar genotypes were obtained from young leaves as described in $\mathrm{Wu}$ et al. [51]. Leaves were cut into $1-2 \mathrm{~mm}$ fine strips in $0.3 \mathrm{M}$ sorbitol and $66.67 \mathrm{mM} \mathrm{CaCl}_{2}$ (pH 5.6) and lysed in an enzyme solution (0.6 M mannitol, $0.25 \%(\mathrm{w} / \mathrm{v})$ cellulase Onozuka R-10, $0.05 \%(\mathrm{w} / \mathrm{v})$ macerozyme R-10) in the dark for $16 \mathrm{~h}$ with gentle shaking ( $30 \mathrm{rpm})$ at room temperature. Protoplasts were collected by filtering the lysate suspension through a $70 \mu \mathrm{m}$ cell strainer $\left(\right.$ Falcon $^{\circledR}$ ) and concentrated by spinning down at $\approx 800 \mathrm{x} g$ for $10 \mathrm{~min}$ at $4{ }^{\circ} \mathrm{C}$. The pellet was washed twice with W5 buffer (154 mM NaCl, $125 \mathrm{mM} \mathrm{CaCl}_{2}, 5 \mathrm{mM} \mathrm{KCl}, 5 \mathrm{mM}$ glucose, $0.03 \%(\mathrm{w} / \mathrm{v})$ MES, pH 5.8) and then resuspended in $0.6 \mathrm{M}$ mannitol to a final concentration of $1 \times 10^{6}$ protoplasts per mL. Protoplasts $\left(1.10^{6}\right)$ were incubated at $20{ }^{\circ} \mathrm{C}$ with gentle shaking (40 rpm) for $3 \mathrm{~h}$ with aphid salivary proteins or with protein extraction buffer (control). This incubation duration allowed to observe early gene response to salivary effectors before cell walls start to replenish [52]. RNA extraction was done just after the saliva or control treatment (see 2.3.4). Preliminary experiments investigating expression of 5 poplar genes, and conducted with $1,10,20,40$ or $80 \mu \mathrm{g}$ of salivary proteins, indicated that the optimal response (i.e. the maximum fold change) was observed with $1 \mu \mathrm{g}$ of salivary proteins of $P$. passerinii and $10 \mu \mathrm{g}$ of salivary proteins of $M$. persicae (Fig. S2). Protoplast viability, before and after treatment with aphid saliva, was assessed using $0.005 \%(\mathrm{w} / \mathrm{v})$ fluorescein diacetate (FDA). After $5 \mathrm{~min}$ of incubation protoplasts were observed under blue light epifluorescence, and cell viability was estimated as the percentage of fluorescent cells. Most protoplasts were intact and viable after enzymatic digestion with cellulase and macerozyme (98\%), as well as after incubation with salivary proteins (95 \%; Fig. S3).

\subsubsection{Quantitative RT-PCR}

After the aphid saliva treatments, protoplasts were centrifuged at $\approx$ $800 \mathrm{x} g$ for $2 \mathrm{~min}$. Total RNAs were then immediately extracted with the RNeasy ${ }^{\circledR}$ Plant Kit Mini Kit (Qiagen). A DNase treatment with the RNase-free DNase Set (Qiagen) was carried out for $15 \mathrm{~min}$ at $25{ }^{\circ} \mathrm{C}$. Total RNA concentration was determined using a Nanodrop ND-1000 spectrophotometer. All RNA samples were rejected if they did not reach a minimum concentration of $100 \mathrm{ng} \mathrm{L}^{-1}$, a $260 \mathrm{~nm} / 280 \mathrm{~nm}$ ratio between 1.8 and 2.0. Poly(dT) cDNA was prepared from $1 \mu \mathrm{g}$ total RNA using the iScriptTMcDNA Synthesis Kit (Bio-Rad) and quantified with a LightCycler 480 (Roche) and SYBR GREEN I Master (Roche), according to the manufacturer's instructions. PCR was carried out in 384-well optical reaction plates heated for $10 \mathrm{~min}$ to $95{ }^{\circ} \mathrm{C}$ to activate hot start Taq DNA polymerase, followed by 40 cycles of denaturation for $60 \mathrm{~s}$ at $95{ }^{\circ} \mathrm{C}$ and annealing/extension for $60 \mathrm{~s}$ at $58{ }^{\circ} \mathrm{C}$. The distribution of the quantitative RT-PCR mix containing SYBR Green I Master (Roche), cDNAs and primers was performed using the EVO150@ (Tecan) pipetting robot in a 384-well plate. The expression of 43 genes, belonging to eight different physiological processes or metabolic pathways (i.e. auxin, cytokinins, jasmonates, ethylene, salicylic acid, phenolic compounds, reactive oxygen species (ROS), cell-division cycle), was quantified with specific primer pairs designed by Quant-Prime [53] based on the Populus trichocharpa sequence (v3.0) from Phytozome (https:// phytozome.jgi.doe.gov/pz/portal.html; Table S2). Expression levels were normalized to the levels of PtUBIQUITIN10 (PtUBQ10), commonly used as a reference gene in plants e.g. [54]. All RT-qPCR experiments were done with three independent biological replicates, with two technical replicates each. One of the biological replicates of the $M$. persicae - Koster interaction was excluded from the analyses because of technical issues during quantification. Relative gene expression was calculated according to the ${ }^{\Delta \Delta} \mathrm{Ct}$ method, with protoplasts incubated with protein extraction buffer as controls. Primers used for gene expression analysis are listed in Table S2.

\subsubsection{Histochemical analysis of GUS activity}

Transgenic seedlings of $A$. thaliana (five-day-old and eight-day-old for pIAA2::GUS and pARR16: GUS, respectively) were incubated with 2 $\mathrm{mL}$ of liquid MS containing $1 \mu \mathrm{g}$ and $10 \mu \mathrm{g}$ of aphid salivary proteins (in TE/Tween buffer) of either $P$. passerinii or $M$. persicae for $3 \mathrm{~h}$ and $4 \mathrm{~h}$ for pIAA2::GUS and pARR16: GUS, respectively. Positive controls were incubated with $20 \mu \mathrm{M}$ of indole acetic acid (IAA) (Sigma-Aldrich), and 20 $\mu \mathrm{M}$ of 6-benzylaminopurine (BAP) (Sigma-Aldrich). Negative controls were incubated in liquid MS and corresponding volumes of TE/Tween buffer. Five seedlings were used for each modality. Seedlings were then incubated in reaction buffer containing $0.1 \mathrm{M}$ sodium phosphate buffer (pH 7), $2 \mathrm{mM}$ ferricyanide, $2 \mathrm{mM}$ ferrocyanide, $0.1 \%$ (v/v) Triton X100 and $1 \mathrm{mg} \mathrm{ml}^{-1} \mathrm{X}$-Gluc for 1 up to $24 \mathrm{~h}$ in dark at $37^{\circ} \mathrm{C}$. Afterwards, chlorophyll was removed by destaining in $70 \%$ ethanol and seedlings were cleared as described by Malamy and Benfey [55]. GUS expression was monitored by differential interference contrast microscopy.

\subsection{Data analysis}

All tests were carried out with the statistical software R 2.11.0 [56]. RT-qPCR results were expressed as fold-changes in gene expression compared to the reference gene PtUBQ10. Fold-changes were $\log _{2}$ transformed. Following this transformation, fold-changes varied between $-\infty$ and $+\infty$, with negative values corresponding to gene underexpression, positive values to overexpression and zero, to no change in gene expression. To visualize similarities and differences in foldchanges a heatmap was built, with genes in columns and modalities in lines. The heatmap was built with a Z-score, i.e. $\log _{2}$ - transformed fold changes which were normalized and centered per column. Hierarchical 
clustering, using Pearson correlation as similarity metric, was performed to visualize the proximity among genes in columns and among modalities in lines. The uncertainty of hierarchical clustering of modalities was assessed with approximately unbiased p-values calculated with a multiscale bootstrap resampling, with 10,000 bootstrap replications, using the function pvclust() [57]. T-tests were performed with ${ }^{\Delta} \mathrm{Ct}$ values to detect significant changes in expression for each saliva treatment vs. controls. An analysis of variance, followed with a Tukey test when significant, was also performed to compare the effect of treatment modalities (i.e. aphid species and host genotype combinations) on $\log _{2}$-fold changes of each gene.

\section{Results}

\subsection{Annotation, secreted proteins detection and identification}

From 36,312 and 3233 transcripts, 1243 and 221 transcripts were predicted to encode for secreted salivary proteins in $P$. passerinii and $M$. persicae, respectively. About half of them (604) were annotated for $P$. passerinii and 190 for M. persicae. Using OrthoVenn, 121 and 58 protein clusters were identified for $P$. passerinii and $M$. persicae, respectively. About $17 \%$ of these clusters were common between the two aphids (Table S3).

Blast2GO determined that $P$. passerinii salivary gland encoded proteins were predominantly binding proteins and enzymes (Fig. 1, table S4). The most common enzymes were peptidases (especially serine-type and cysteine-type endopeptidases), kinases (especially phosphatidylinositol phosphate (PIP) kinases) and hydrolases. Several enzymes involved in the degradation of carbohydrates (i.e. cellulase, trehalase, $\beta$ glucuronidase, mannosidase and glucosylceramidase), and of phenolic compounds (i.e. peroxidase and oxidoreductase) were also identified (Fig. 1, table S4). Among binding proteins, dimerization protein, nucleic acids binding (especially DNA binding), nucleotide binding (especially ATP binding) and cation-binding (mostly calcium ionbinding and zinc-binding proteins) were the most commonly found (Fig. 1, table S4). Proteins related to hormone activity were also identified. Glucose dehydrogenases were also detected with OrthoVenn (table S3). Among the 12 aphid salivary effectors considered, five were identified in $P$. passerinii, with low E-values $\left(<7 \mathrm{e}^{-71}\right)$ : Mp10, ARMET,

\section{ACE 1, ACE2 and ACE3.}

\subsection{Enzyme activities}

Staining with Coomassie blue confirmed the protein nature of the salivary sheath material (Fig. 2A) and DOPA staining indicated a phenoloxidase activity in the sheaths (Fig. 2B). Black halos were also observed around some sheaths (Fig. 2B). Likewise, peroxidase activity was found in salivary sheaths and halos around sheaths (Fig. 2C). However, no pectinesterase, polygalacturonase and proteinase activity was detected.

\subsection{Quantitative poplar gene expression}

An overview of poplar genes responses to aphid saliva is presented in Fig. 3. The hierarchical clustering of modalities (left dendrogram) showed that all biological replicates of interactions with the salivary proteins of $M$. persicae (i.e. non-host species interactions) were grouped within a significant cluster, in which a majority of poplar genes were upregulated. Within this cluster, replicates were not arranged according to poplar genotype. Biological replicates of the interaction between salivary proteins of $P$. passerinii and Koster (i.e. the host species - resistant genotype) also clustered together, although the cluster was significant for only two replicates. In this group, a majority of genes were weakly expressed or upregulated. For biological replicates of the interaction between salivary proteins of $P$. passerinii and I-214 (i.e. the host species - susceptible genotype), a majority were weakly expressed or downregulated. Nonetheless, these replicates were not significantly clustered together. The hierarchical clustering of genes (upper dendrogram) showed that there was no clustering of genes according to physiological process or metabolic pathway.

For the auxin pathway, during non-host species interactions between salivary proteins of $M$. persicae and both poplar genotypes biosynthetic genes were either not affected (PtYUCCA) or downregulated (PtNIT1) while PtGH3, which is involved in auxin inactivaton via conjugation, was upregulated (Fig. 4). PtAPB1 (signaling) and PtPIN1 (auxin efflux carrier) were also significantly upregulated, but only during the interaction between $M$. persicae and I-214. No change was observed in the expression of the auxin influx carrier PtAUX1. For $P$.

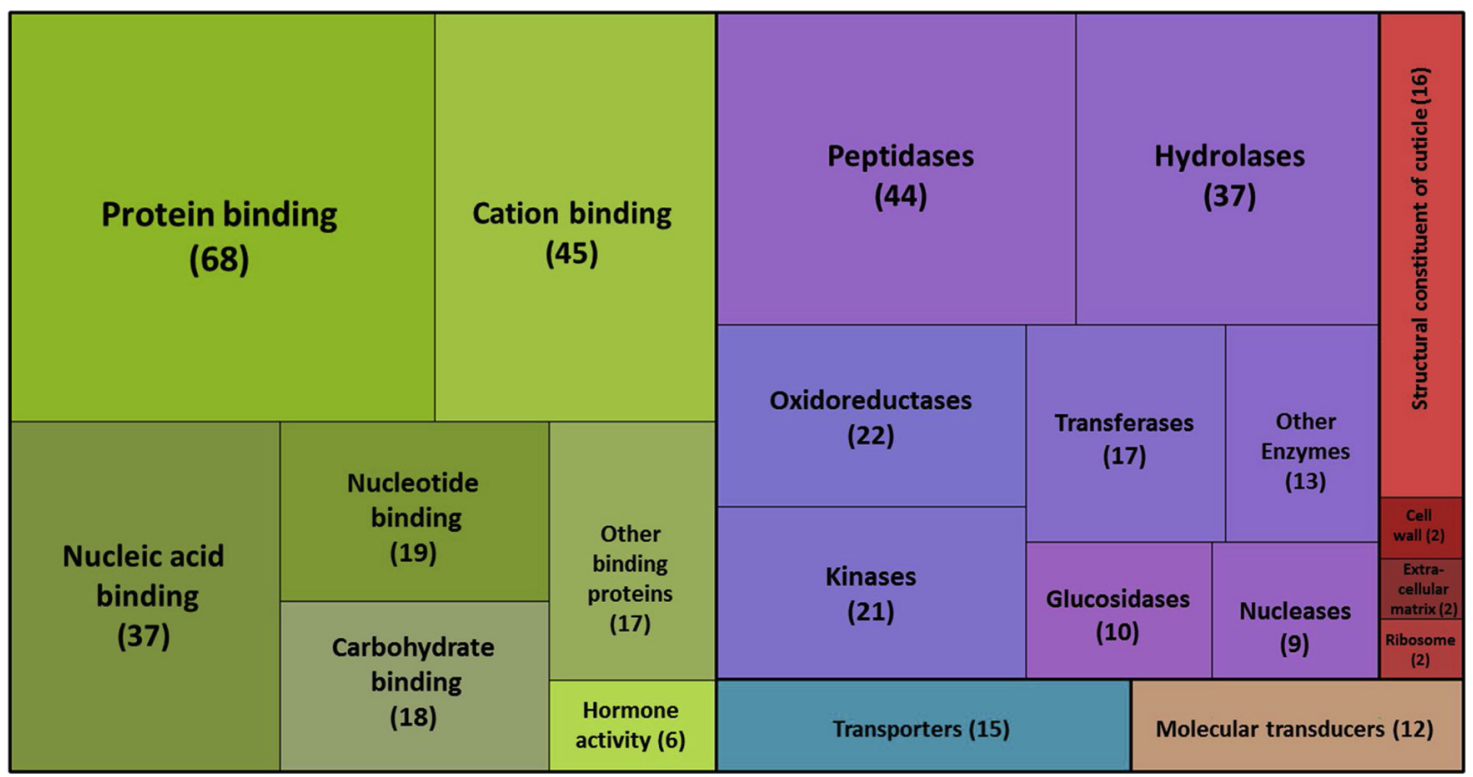

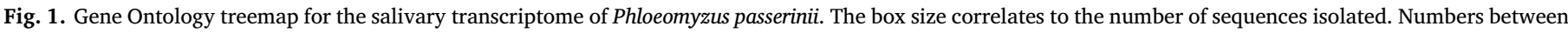

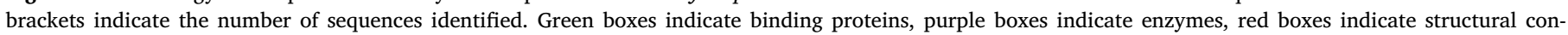

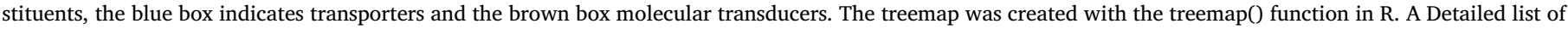

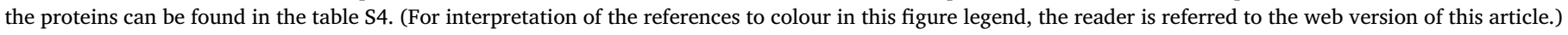




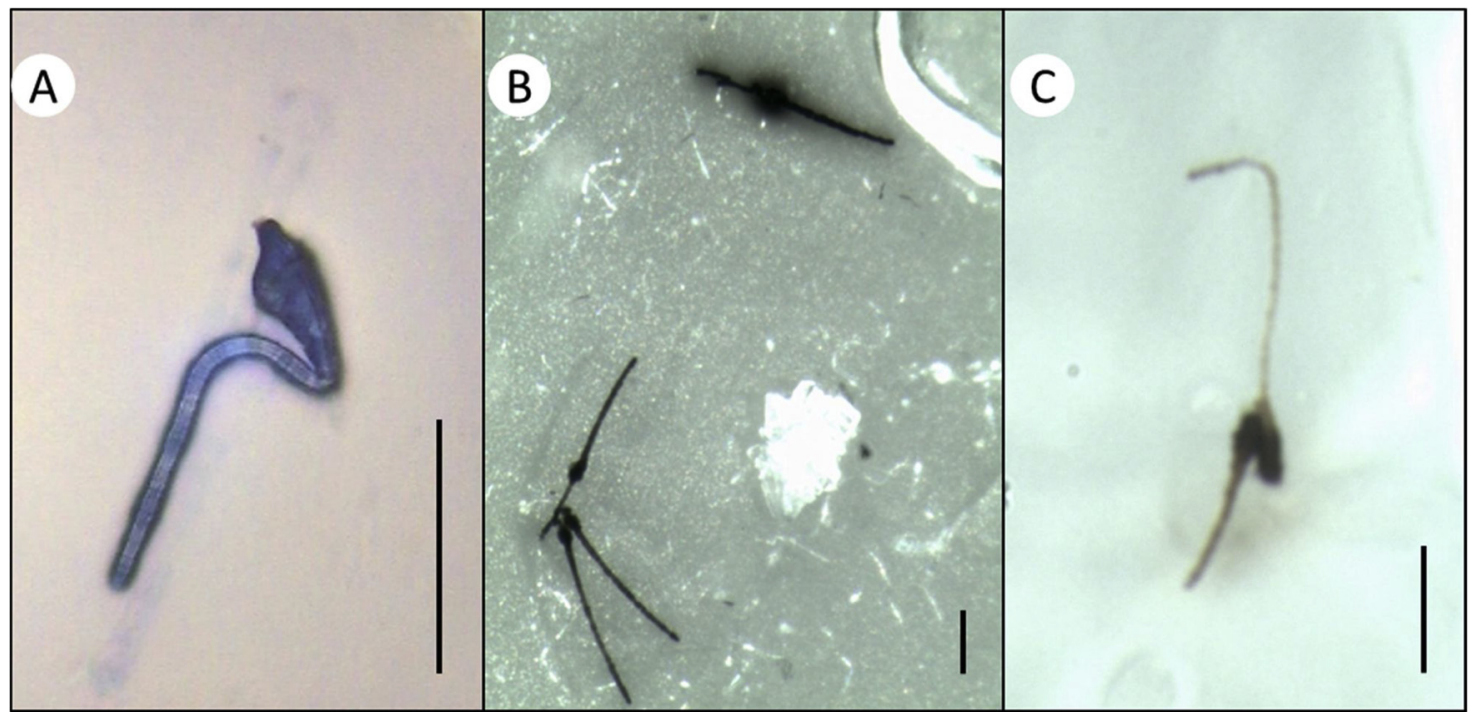

Fig. 2. Representative salivary sheaths secreted in artificial diets by Phloeomyzus passerinii. Sheaths stained and observed after $24 \mathrm{~h}$ probing in an agarose diet: (A) sheath stained with Coomassie blue; (B) black stained sheaths in diet containing $0.1 \%$ DOPA, indicating a phenoloxidase activity, note the dark halo surrounding the upper sheath; (C) reddish stained sheath in diet immersed with $0.1 \% \mathrm{DAB}$ and $0.1 \% \mathrm{H}_{2} \mathrm{O}_{2}$, indicating a peroxidase activity. Black bars represent $10 \mu \mathrm{m}$. (For interpretation of the references to colour in this figure legend, the reader is referred to the web version of this article.)

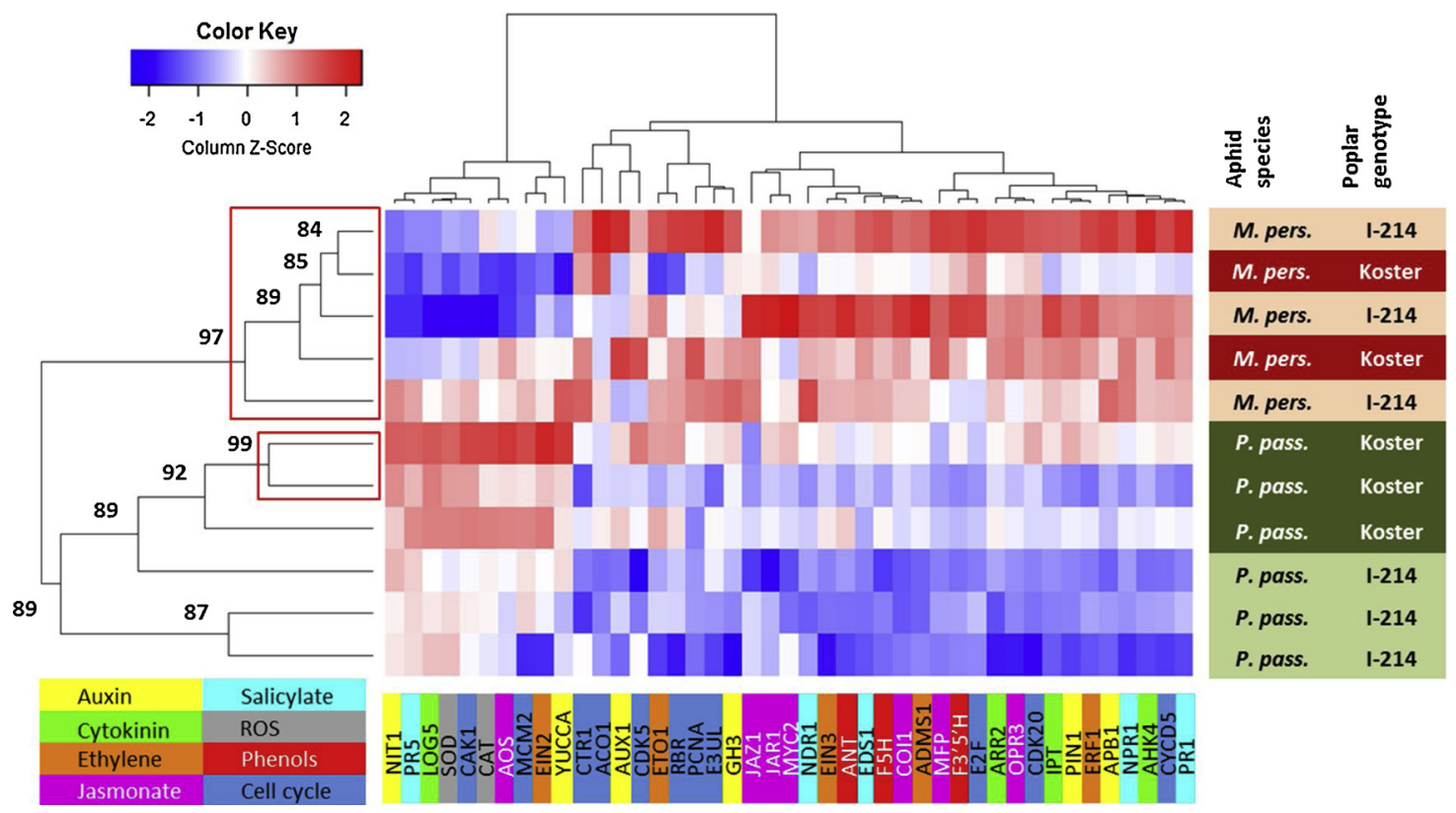

Fig. 3. Heatmap of $\log _{2}$-fold changes of 43 poplar genes belonging to eight different physiological processes or metabolic pathways (lower left box), after incubation of poplar protoplasts of two poplar genotypes (Koster and I-214) with salivary proteins of two aphids (Myzus persicae (M. pers.) and Phloeomyzus passerinii (P. pass.)). Non-host species interactions are expected between both poplar genotypes and $M$. persicae. Poplar is a host plant for $P$. passerinii but Koster is a resistant genotype while I-214 is a susceptible genotype. Downregulation appears in blue and upregulation in red. Gene code is presented below the heatmap, modalities (i.e. aphid $\mathrm{x}$ poplar genotype combinations are presented on the right of the heatmap). Hierarchical clustering was built with distances based on Pearson correlations. Approximately unbiased p-values (\%) are indicated for the hierarchical clustering of modalities, red boxes indicate significant clusters at $\alpha=0.05$. (For interpretation of the references to colour in this figure legend, the reader is referred to the web version of this article.)

passerinii, during the interaction with Koster these genes displayed an expression profile quite similar to that observed during non-host species interactions with $M$. persicae, except for PtNIT1 whose expression was not affected. The expression of PtGH3 was significantly downregulated during the interaction between salivary proteins of $P$. passerinii and I214, and PtGH3, PtAPB1 and PtPIN1 were differentially expressed during the interaction with this susceptible genotype compared to nonhost species interactions with $M$. persicae, and compared to the interaction with the resistant genotype for PtAPB1 only (Fig. 4).

For the cytokinin pathway, during the non-host species interaction between salivary proteins of $M$. persicae and I-214 PtIPT (biosynthesis), PtAHK4 (perception) and PtARR2 (signaling) were upregulated while PtLOG5 (metabolism) was significantly downregulated (Fig. 4). A similar expression profile was observed during the non-host species interaction with Koster, but only PtAHK4 and PtLOG5 were significantly affected. These genes were not significantly affected during the interaction between salivary proteins of $P$. passerinii and Koster. In contrast, PtARR2 was strongly repressed during the $P$. passerinii - I-214 interaction, and PtAHK4 and PtARR2 were differentially expressed during this interaction compared to the other ones (Fig. 4). 


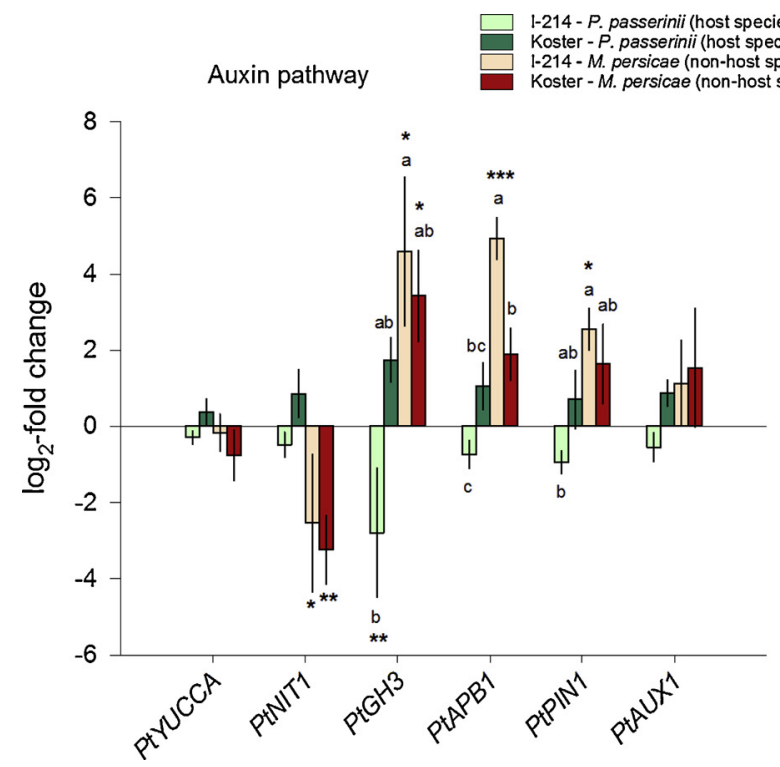

-214 - P. passerinii (host species susceptible genotype) Koster - M. persicae (non-host species)

$$
\text { (pecies) }
$$
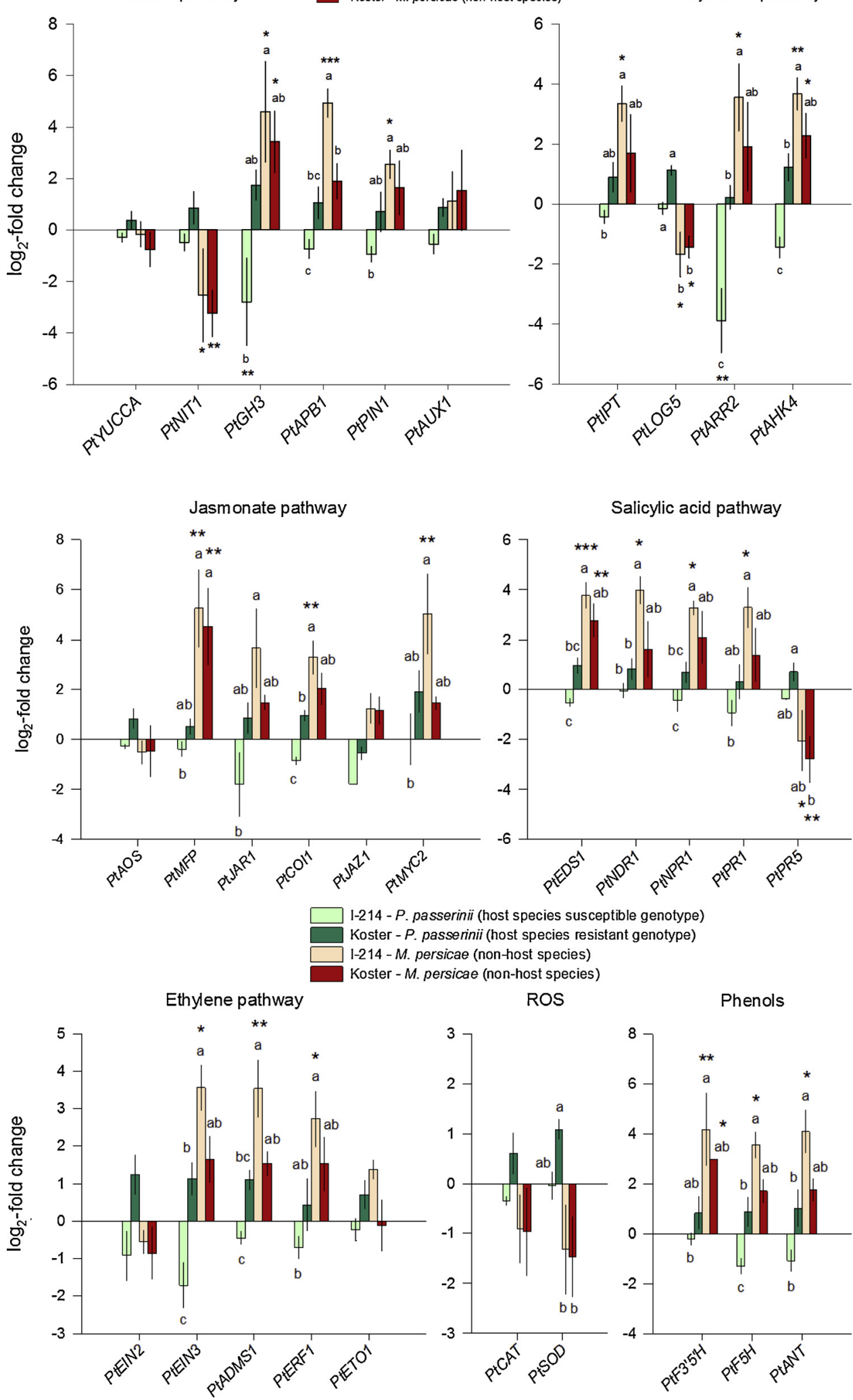

Regarding biotic stress signaling (i.e. jasmonates, salicylic acid, ethylene and ROS), non-host species interactions were characterized by a marked upregulation of a majority of genes, which was more frequently significant for the interaction with I-214 than for the interaction with Koster (Fig. 5). Few genes in jasmonate ethylene and ROS
ROS
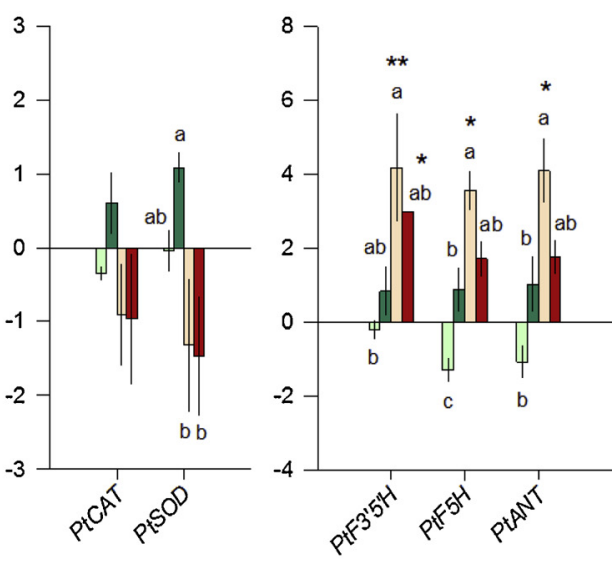

Fig. 4. Mean ( \pm SE) $\log _{2}$-fold changes of genes involved in auxin (left) and cytokinin (right) pathways of poplar protoplasts collected from two poplar genotypes (I-214 and Koster), after incubation with salivary proteins of two aphids (Myzus persicae and Phloeomyzus passerinii), resulting in resistant or susceptible interactions with a host species or non-host species interactions. Stars indicate modalities for which a significant upregulation or downregulation of gene expression vs. controls was observed, using ${ }^{\Delta} \mathrm{Ct}$ values (t-test). ${ }^{* * *}$, ** and * indicate a significant effect with $\mathrm{P}<0.001$, $\mathrm{P}<0.01$ and $\mathrm{P}<0.05$, respectively. Different letters indicate significantly different groups (Tukey test) of $\log _{2}$-fold changes among modalities, for each gene.

Fig. 5. Mean ( \pm SE) $\log _{2}$-fold changes of genes involved in jasmonate, salicylic acid, ethylene pathways, ROS responses and phenolic compounds of poplar protoplasts collected from two poplar genotypes (I-214 and Koster), after incubation with salivary proteins of two aphids (Myzus persicae and Phloeomyzus passerinii), resulting in resistant or susceptible interactions with a host species or non-host species interactions. Stars indicate modalities for which a significant upregulation or downregulation of gene expression vs. controls was observed, using ${ }^{\Delta} \mathrm{Ct}$ values (t-test). ${ }^{* * *},{ }^{* *}$ and * indicate a significant effect with $\mathrm{P}<0.001$, $\mathrm{P}<0.01$ and $\mathrm{P}<0.05$, respectively. Different letters indicate significantly different groups (Tukey test) of $\log _{2}$-fold changes among modalities, for each gene. pathways were not affected by salivary extracts of $M$. persicae (i.e. PtAOS, PtJAZ1, PtEIN2, PtETO1, PtCAT and PtSOD), and, in the salicylic acid pathway, PtPR5 was significantly downregulated. For interactions with salivary proteins of $P$. passerinii, all genes were weakly downregulated during the interaction with the susceptible genotype. In 
contrast, during the interaction with the resistant genotype most genes were either not affected or exhibited profiles as during non-host species interactions with $M$. persicae, with weak upregulations. Nonetheless, for these modalities, no gene expression significantly differed from the controls (Fig. 5). In most cases, gene expressions during the interaction with the susceptible genotype were significantly lower than during nonhost species interactions with I-214, and, in fewer cases, lower than during non-host species interactions with Koster. For interactions with P. passerinii, only PtCOI1 and PtEIN3 genes were differentially expressed during interactions with either the susceptible or the resistant genotype. Conversely, since gene expressions during interactions with the resistant genotype were weakly upregulated, they generally did not differ from those observed during non-host species interactions with Koster, and differed from non-host species interactions with I-214 for only several genes (i.e. PtCOI1, PtEDS1, PtNPR1, PtNDR1, PtEIN3, PtADMS1). Nonetheless, PtPR5 and PtSOD were clearly differentially expressed between host and non-host interactions with Koster.

For genes involved in the phenolic compounds pathway (Fig. 5), non-host species interactions, especially with I-214, led to an upregulation of all the considered genes. All genes were weakly, but not significantly, downregulated or upregulated during interactions between the saliva of $P$. passerinii and either the susceptible genotype or the resistant genotype, respectively. For I-214, gene expression was always significantly lower during the interaction with the saliva of $P$. passerinii compared to the interaction with the saliva of M. persicae. For PtF5H, expression was also significantly lower during the $P$. passerinii - I-214 interaction compared to other interactions.

Finally, regarding genes involved in cell-division cycle, PtCDK5, PtPCNA, PtCDK2O and PtE2F were significantly upregulated during nonhost species interactions with $M$. persicae, while PtCAK1 was significantly downregulated (Fig. 6). PtCYCD5 and PtACO1 were also upregulated but only during non-host species interactions with I-214. Likewise, PtCDK5 and PtCDK20 were also significantly upregulated during the $P$. passerinii - Koster interaction, as well as PtCAK1. Expression of PtMCM2 and PtRBR was not affected by salivary extracts. PtCDK20 was differentially expressed during the P. passerinii - I-214 interaction compared to other ones. Likewise, during the $P$. passerinii Koster interaction the expression of PtCTR1 was much lower compared to non-host species ones and expression of PtE3UL, PtE2F and PtACO1 were lower compared to expression during non-host species interactions with I-214. For PtCAK1, the expression was higher during the $P$. passerinii - Koster interaction than during non-host species ones.

\subsection{Histochemical analysis of GUS activity}

Salivary extracts of $P$. passerinii increased pIAA2::GUS signals
(Fig. 7E, 7 F, 7I, 7 J), which were similar to those caused by an exogenous application of auxin (Fig. 7A and 7B). Incubation with salivary proteins of $M$. persicae resulted in faint colorations (Fig. 7G, 7H, 7 K, 7 L), similar to those of negative controls (Fig. 7C and 7D).

Positive controls of pARR16: GUS were characterized by a strong staining in the middle part of root central cylinder (Fig. 8A and 8B), which was weak in negative controls as well as with $M$. persicae salivary proteins (Fig. 8G, 8H, $8 \mathrm{~K}$, and $8 \mathrm{~L}$ ). No coloration was visible in the roots of seedlings incubated with salivary proteins of $P$. passerinii (Fig. 8E, $8 \mathrm{~F}, 8 \mathrm{I}$ and $8 \mathrm{~J}$ ).

\section{Discussion}

Successful plant colonization by parasites generally requires the circumvention or inactivation of host defenses, and sometimes a finely tuned reprogramming of host metabolism. As a consequence, the lifestyle and feeding strategy of parasites should have both quantitative and qualitative outcomes on their secretome e.g. [11,58]. In line with this, comparisons among salivary proteins of aphid species also indicated that aphids with different host species and / or feeding strategies exhibited very different salivary protein profiles $[59,60]$. Our results tend to support this assertion since the predicted salivary gland proteins of $P$. passerinii and $M$. persicae shared few similarities, and poplar gene expression profiles markedly differed when protoplasts were exposed to salivary proteins of these two aphid species. The salivary transcriptome of $P$. passerinii also holds specific and abundant PIP kinases sequences, which have never been reported from any other aphid saliva. Nonetheless, several protein functions predicted in our study (e.g. calcium-binding, DNA-binding, ATP-binding, GTP-binding proteins, glucose dehydrogenases, oxidoreductases, trehalases and phosphatases) have also been identified in the saliva of different sapfeeding aphid species $[22,59,61,62]$, and in secretions of other plant parasites $[3,63]$. Interestingly, calcium-binding proteins are supposedly key components of the saliva of sap-feeding aphids, preventing the plugging of sieve tubes [4]. Since P. passerinii does not feed on sap [19], it suggests that these proteins also play other crucial roles during aphidplant interactions. In addition to their different feeding strategies, the two aphid species are also phylogenetically distant [27], which should further increase the dissimilarity of their secretomes. It should be noted also that the transcriptomes of $P$. passerinii and $M$. persicae have been obtained with a different sequencing and assembly methods [64]. This probably explains the difference in transcripts amounts gathered for both aphids and several encoded proteins in salivary glands of $M$. persicae might be missing in its transcriptome, leading to an apparently low similarity between secretomes. Likewise, the lack of biological replicates for both transcriptomes might have also led to an

\section{Cell-division cycle}

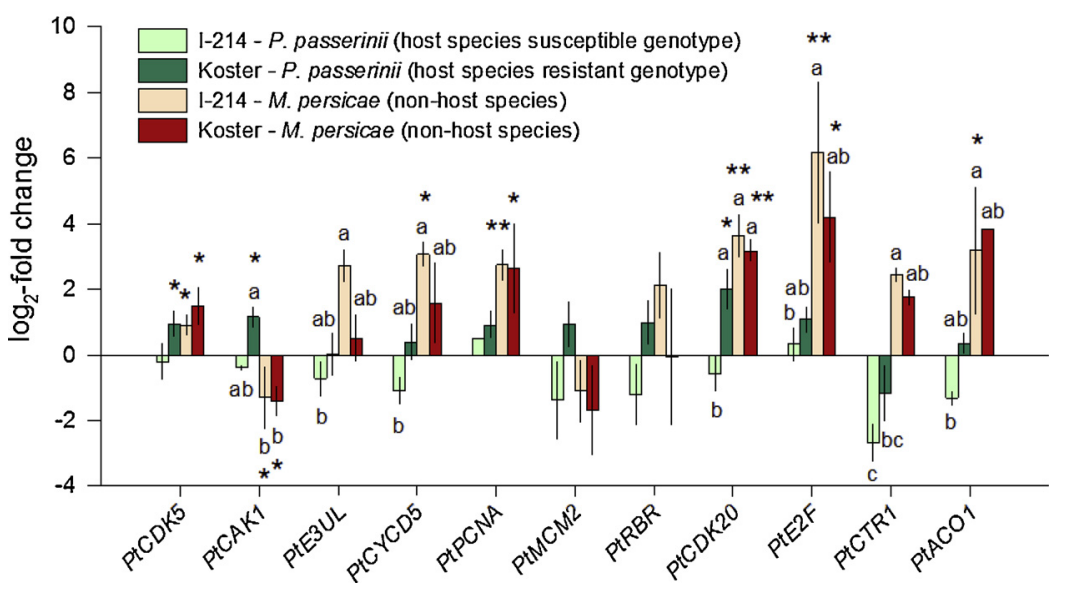

Fig. 6. Mean ( $\pm S E$ ) $\log _{2}$-fold changes of genes involved in celldivision cycle of poplar protoplasts collected from two poplar genotypes (I-214 and Koster), after incubation with salivary proteins of two aphids (Myzus persicae and Phloeomyzus passerinii), resulting in resistant or susceptible interactions with a host species or non-host species interactions. Stars indicate modalities for which a significant upregulation or downregulation of gene expression vs. controls was observed, using ${ }^{\Delta} \mathrm{Ct}$ values (t-test). ** and * indicate a significant effect with $\mathrm{P}<0.01$ and $\mathrm{P}<0.05$, respectively. Different letters indicate significantly different groups (Tukey test) of $\log _{2}$-fold changes among modalities, for each gene. 

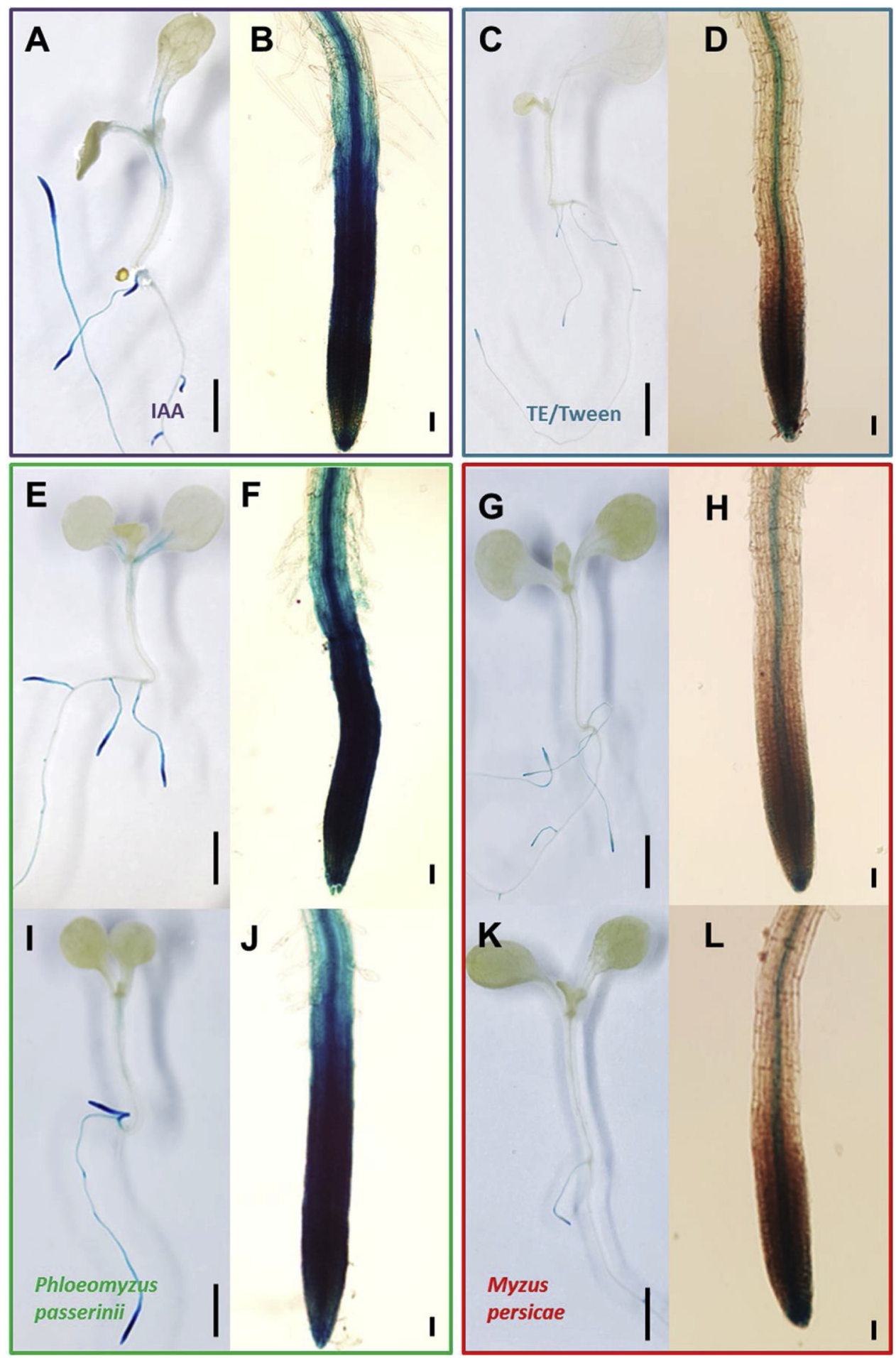

Fig. 7. Representative GUS assays of transgenic seedlings of Arabidopsis thaliana pIAA2: GUS, showing whole plants (A, C, E, G, I and K), and root tips (B, D, F, H, J and L), after $3 \mathrm{~h}$ of incubation in $20 \mu \mathrm{M}$ of IAA (A and B), TE/Tween buffer ( $\mathrm{C}$ and D), and 1 and $10 \mu \mathrm{g}$ of salivary proteins of Phloeomyzus passerinii (E, F, I and J) or Myzus persicae (G, H, K and L). Black bars represent $1 \mathrm{~mm}$ for whole plants (A, C, E, G, I and K) and $10 \mu \mathrm{m}$ for root tips (B, D, F, H, J and L). Five seedlings were used for each modality.

underestimation of the similarity between secretomes.

Several encoded proteins detected in the salivary glands of $P$. passerinii may interfere with host defenses via direct interactions with secondary metabolites or defense proteins. The interaction between $P$. passerinii and susceptible poplar genotypes is characterized by transient accumulation of phenolic compounds, which fade away during later stages of the interaction [20]. Salivary effectors might contribute to the degradation of these secondary metabolites as numerous oxidoreductase sequences were identified in the salivary gland transcriptome of $P$. passerinii. Moreover, in situ biochemical assays confirmed the presence of active peroxidases and phenoloxidases in both solid and soluble saliva fractions of $P$. passerinii. The predicted glucose dehydrogenases may also help $P$. passerinii to detoxify defensive compounds of the host-plant $[11,60]$. Likewise, plant defense proteins might be inactivated by the numerous protein-binding proteins and proteases predicted among the salivary gland encoded proteins of $P$. 

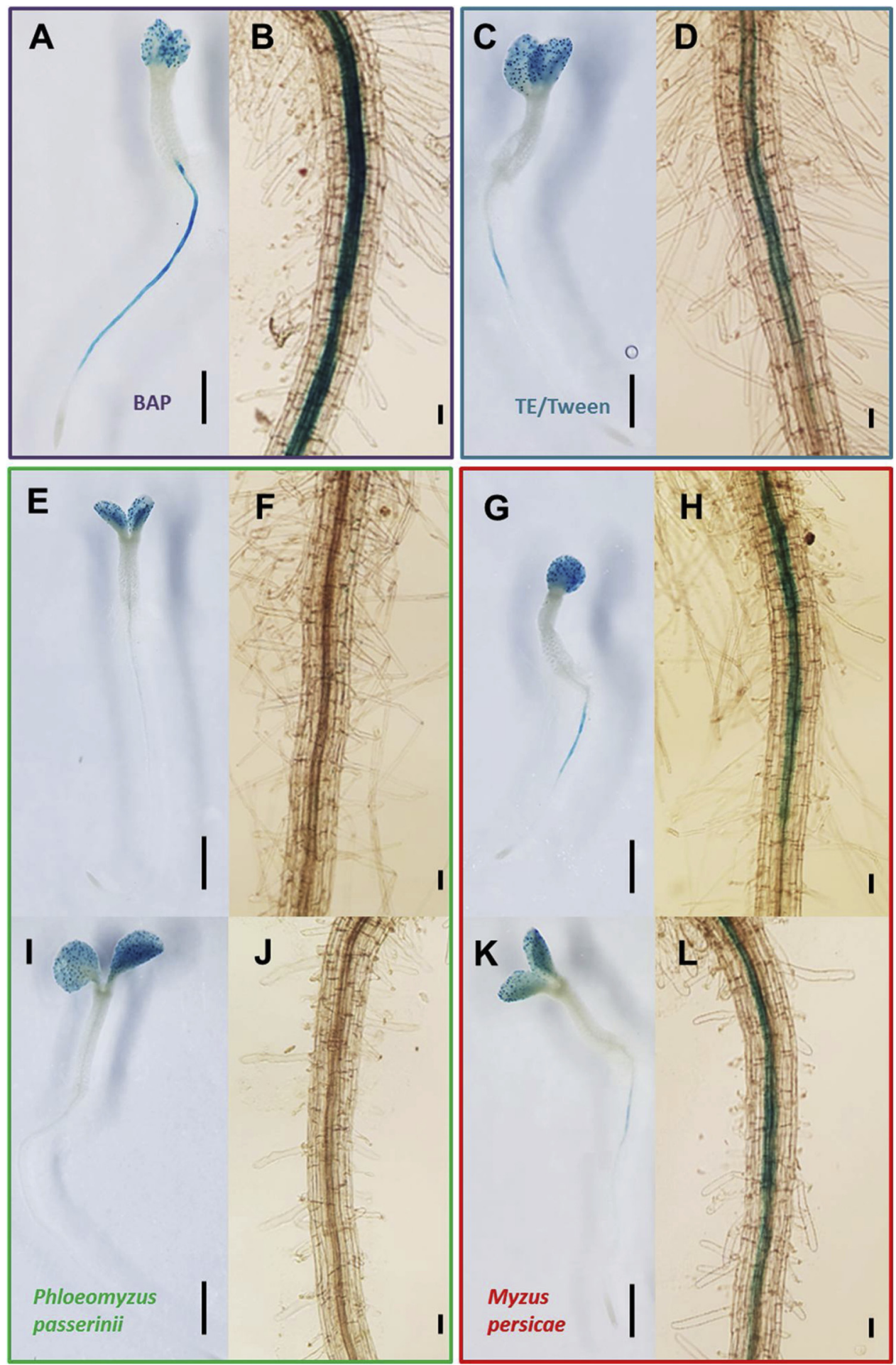

Fig. 8. Representative GUS assays of transgenic seedlings of Arabidopsis thaliana pARR16: GUS, showing whole plants (A, C, E, G, I and K), and root tips (B, D, F, H, J and L), after $4 \mathrm{~h}$ of incubation in $20 \mu \mathrm{M}$ of BAP (A and B), TE/Tween buffer (C and D), and 1 and $10 \mu \mathrm{g}$ of salivary proteins of Phloeomyzus passerinii (E, F, I and J) or Myzus persicae (G, H, K and L). Black bars represent $1 \mathrm{~mm}$ for whole plants (A, C, E, G, I and K) and $10 \mu \mathrm{m}$ for root (B, D, F, H, J and L). Five seedlings were used for each modality.

passerinii. Parasites frequently secrete similar effectors to degrade or modulate the plant enzymes activities [3]. Nonetheless, no protease activity was observed during in situ bioassays. Gelatin was probably not the adequate substrate to detect the protease activity of $P$. passerinii. Additional in situ assays could be conducted to detect, in $P$. passerinii saliva, the activity of the proteases and possibly other enzymes like cellulases. A proteomic analysis of salivary extracts should also confirm and complement the predictions of our transcriptomic approach $[65,66]$.

Several salivary gland encoded proteins may also affect host defense via a disruption of biotic stress signaling. PIP kinases catalyze phosphorylation of phosphatidyl-inositol into phosphatidylinositol-4-5-biphosphate $\left(\mathrm{PIP}_{2}\right)$. The hydrolysis of $\mathrm{PIP}_{2}$ produces secondary messengers like inositol-1-4-5-triphosphate $\left(\mathrm{IP}_{3}\right)$ and diacylglycerol (DAG). 
This latter can in turn be hydrolyzed into phosphatidic acid (PA) considered an important signaling molecule in plants, triggered in response to various biotic and abiotic stresses [67]. PIP $_{2}$ and $\mathrm{IP}_{3}$ might also affect cellular oscillations of cytosolic $\mathrm{Ca}^{2+}$ and are involved in multiple processes including cell cycle and phytohormone regulation [68]. Other proteins, also frequently detected in parasites, including aphids, may also interfere with secondary messengers like calcium-binding, ATPbinding, and GTP-binding proteins or with hormone signaling like hormone-binding proteins $[3,5,6,59]$. Similarly, it has been hypothesized that trehalase may interfere with trehalose-based defense responses in A. thaliana [61].

Finally, several salivary gland encoded proteins could also contribute to the manipulation of host-plant metabolism. For instance, nucleic acid-binding proteins could affect gene expression, while protein-binding and hormone-binding proteins could modulate metabolic and phytohormonal pathways [3,59]. In addition, serine proteases, acid phosphatases, cellulases, lipases and metalloproteases have also been predicted or detected in the secretions of different gall-inducing organisms, and supposedly contribute to gall induction and / or maintenance $[63,69]$.

Both the in vivo approach with protoplasts and the heterologous in planta assay with $A$. thaliana confirmed that salivary proteins of $P$. passerinii impact plant gene transcription, in a specific manner. Gene expression profiles markedly differed, especially in terms of intensity, between non-host species interactions with $M$. persicae and host species interactions with $P$. passerinii. Non-host species interactions led to an upregulation of most genes involved in jasmonate, ethylene and salicylic acid pathways, which are typically activated following aphid feeding, together or separately, depending on the aphid - plant interaction system considered [70-72]. As a consequence, genes related to secondary metabolism, i.e. PtF3' $5^{\prime} H$, PtANT and PtF5H, were also upregulated during these interactions. Conversely, the expression of genes related to biotic stress signaling and defense was either unaffected or slightly downregulated or upregulated during interactions with a susceptible and a resistant genotype of the host species, respectively. This suggests that salivary effectors of $P$. passerinii manage to inactivate or bypass the biotic stress signaling in their host plant, as frequently observed in plant-parasites interactions [1,3]. Non-host species interactions with the two poplar genotypes led to similar gene expression profiles while, for interactions with $P$. passerinii, the expression of several genes differed according to host genotype. Among them, the expression of several genes involved in biotic stress signaling (PtCOI1, PtEIN3), and defense (PtF5H), was significantly higher during the interaction with the resistant genotype than during the interaction with the susceptible one. The overall trend of lack of response or downregulation of genes involved in defense or biotic signaling observed during the interaction between salivary extracts of $P$. passerinii and the susceptible host genotype is congruent with gene expression profiles observed during effector-triggered susceptibility in other plant-parasite systems [73,74].

Although different from the interaction with a susceptible genotype, the interaction between the resistant genotype and $P$. passerinii did not lead to marked upregulations of genes related to biotic stress signaling or defense. Gene expression profiles of poplar protoplasts during the interaction between $P$. passerinii and the resistant poplar genotype shared many similarities with those observed during non-host species interactions with $M$. persicae. Both types of interactions were characterized by an overall upregulation of host genes, which was generally more important during non-host species interactions than during host species interaction with the resistant host genotype, for which only few significant upregulations were observed. Interestingly, two of the three genes that were differentially expressed during non-host and incompatible interactions on the same poplar genotype (i.e. PtPR5 and PtSOD - with a similar trend for PtCAT) were related to biotic stress signaling, and were slightly upregulated during the interaction with the resistant genotype while they were significantly downregulated during non-host species interactions. Effector-triggered immunity is generally a strong defense response, associated with extensive and rapid transcriptional reprogramming [10,74,75]. This was not detected during interactions between $P$. passerinii and the resistant host genotype. Nonetheless the reprograming can take place within few hours [75], and the incubation duration might have been too short to detect an extensive reprogramming. Slightly longer incubation durations might solve this issue.

To knock-down or divert stress signaling parasites may also reconfigure auxin and cytokinin signaling pathways $[1,6,76]$. Both RTqPCR experiments and histochemical assays confirmed that $P$. passerinii can actively manipulate both auxin and cytokinin pathways during an interaction with a susceptible host genotype. Salivary extracts of $P$. passerinii did not affect either auxin biosynthesis or auxin transporter genes such as PtPIN1 and PtAUX1, but significantly downregulated PtGH3, which is involved in the homeostasis of active auxin forms [77]. This could lead to intracellular accumulation of active auxin forms, which is supported by the activation of the auxin-responsive promoter IAA2 during in planta assays with transgenic seedlings of $A$. thaliana. Auxin accumulation could in turn interfere with salicylic acid signaling and defense responses [77], which would be congruent with the overall absence of response of genes related to the salicylic acid pathway

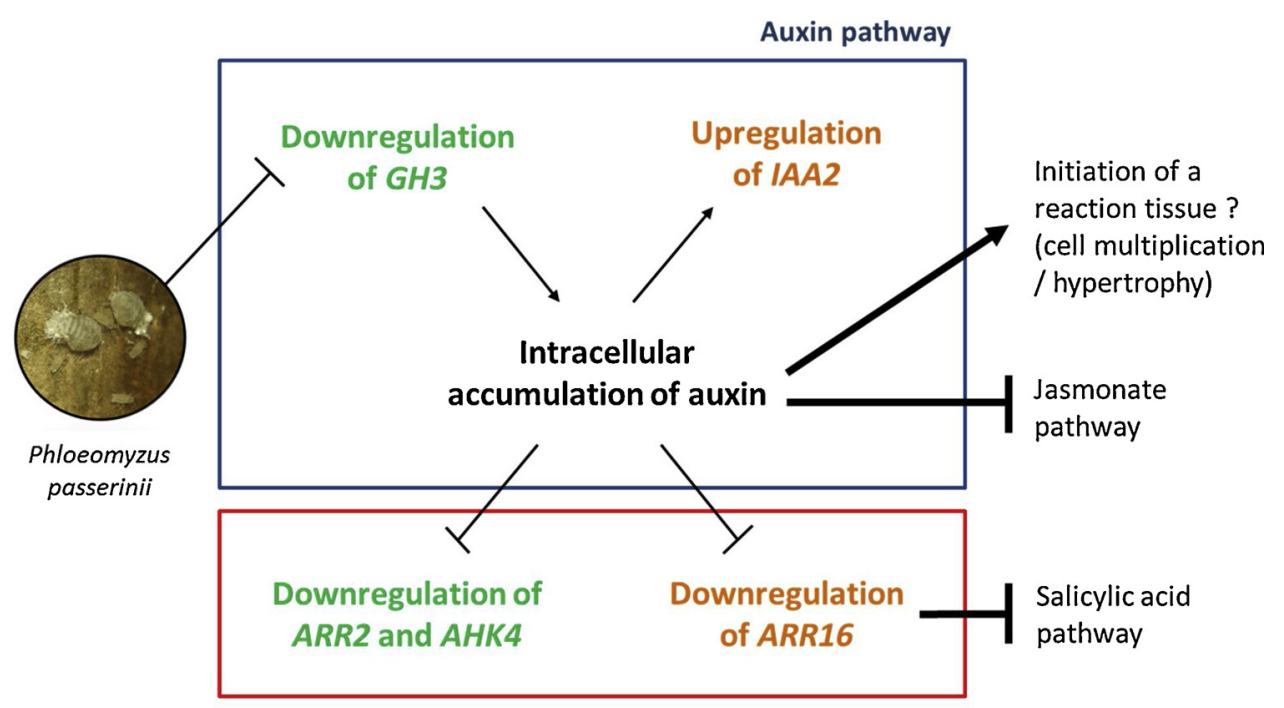

Fig. 9. Graphical summary of effects of salivary extracts of Phloeomyzus passerinii on gene expression in auxin and cytokinin pathways during a compatible interaction based on observations with in vivo RT-qPCR assays with protoplasts (bold green) and heterologous in planta assay (bold orange). (For interpretation of the references to colour in this figure legend, the reader is referred to the web version of this article.)

Cytokinin pathway 
(Fig. 9). As genes related to cytokinin biosynthesis (PtIPT) and activation (PtLOG5) were not affected by salivary proteins of $P$. passerinii, the downregulation of cytokinin perception and signaling genes (PtAHK4 and PtARR2 during the assays with protoplasts and ARR16 during the assay with $A$. thaliana) could correspond to an auxin accumulation-induced regulation loop [78,79]. This downregulation of PtAHK4 and PtARR2 could also interfere with stress signaling by preventing both accumulation of jasmonate and activation of PtPR1 [80] (Fig. 9).

The intracellular accumulation of active auxin forms could also contribute to the targeted cell hypertrophy and multiplication commonly observed in the reaction tissues induced by $P$. passerinii in susceptible poplar genotypes [20] (Fig. 9). Auxin accumulation, as a result of a reduction in both $\mathrm{GH} 3$ activity and auxin transport, is also probably involved in the initiation and development of root galls by cyst and root-knot nematodes [81]. However, exposure of protoplasts of the susceptible genotype to the salivary extracts of $P$. passerinii did not affect expression of genes involved in the cell-division cycle, or weakly downregulated them. Only one gene involved in cell-division cycle (i.e. PtCDK20) was differentially expressed during interactions with either a susceptible or a resistant host genotype. Additional experiments considering genes coding for cell wall remodeling enzymes, activated early during root-knot nematode-induced giant cell differentiation, or for cytoskeleton should provide further insight into the mechanisms associated with the differentiation of hypertrophied cells in this system [73].

In conclusion, our transcriptomic analysis of the saliva of $P$. passerinii and $M$. persicae showed that $P$. passerinii probably secretes a highly peculiar saliva, filled with potential effectors that may interfere with several plant secondary messengers and signaling pathways. Our in vivo approach with protoplasts and in planta approach with a heterologous $A$. thaliana-system confirmed the ability of salivary extracts of $P$. passerinii to interfere with host response during interactions with a susceptible host genotype. As expected auxin and cytokinin pathways were affected, probably to impair biotic stress signaling but also to reconfigure host metabolism and anatomy. Although the saliva of $P$. passerinii and $M$. persicae were very different, interactions with non-host species and with a resistant genotype of a host species led to quite similar host responses, with a different intensity however, and few differences in biotic stress signaling and cytokinin metabolism. Additional modalities including different populations of $P$. passerinii, different poplar genotypes with intermediate resistance levels [18], and additional host metabolic pathways could be considered in future experiments. For instance, investigating how genes coding for NB-LRR proteins, involved in the induction of effector-triggered immunity following the recognition of parasite effectors [10,82], respond to salivary extracts of $P$. passerinii should give further insights into the molecular processes underpinning failed and successful host manipulation by a plant-manipulating organism.

\section{Authors' contribution}

AC, AS and DG conceived the ideas. JD, AC and AS designed methodology. LPL, JD and FL collected the plant-related data. JT, QC, $\mathrm{CH}$ and EH collected the insect-related data. LPL and JT analyzed the data. AC and AS led the writing of the manuscript. All authors have read and approved the manuscript.

\section{Funding}

This work was supported by the Région Centre-Val de Loire Project no. 2014 00,094,521 InsectEffect coordinated by D. Giron.

\section{Declarations of Competing Interest}

None.

\section{Acknowledgements}

We thank Léa Fléchon for her assistance with transcriptome analyses. We are also grateful to the reviewers for their valuable comments.

\section{Appendix A. Supplementary data}

Supplementary material related to this article can be found, in the online version, at doi:https://doi.org/10.1016/j.plantsci.2020.110468.

\section{References}

[1] S.A. Hogenhout, R.A. Van der Hoorn, R. Terauchi, S. Kamoun, Emerging concepts in effector biology of plant-associated organisms, Mol. Plant Microbe Interact. 22 (2009) 115-122.

[2] S.A. Hogenhout, J.I. Bos, Effector proteins that modulate plant-insect interactions, Curr. Opin. Plant Biol. 14 (2011) 422-428.

[3] J. Win, A. Chaparro-Garcia, K. Belhaj, D.G.O. Saunders, K. Yoshida, S. Dong, S. Schornack, C. Zipfel, S.A. Hogenhout, S. Kamoun, Effector biology of plant-associated organisms: concepts and perspectives, Cold Spring Harb. Symp. Quant. Biol. 77 (2012) 235-247.

[4] T. Will, W.F. Tjallingii, A. Thönnessen, A.J. van Bel, Molecular sabotage of plant defense by aphid saliva, Proc. Nat. Acad. Sci. U.S.A. 104 (2007) 10536-10541.

[5] A. Guiguet, G. Dubreuil, M.O. Harris, H. Appel, J.C. Schultz, M.H. Pereira, D. Giron, Shared weapons of blood- and plant-feeding insects: surprising commonalities for manipulating hosts, J. Ins. Physiol. 84 (2016) 4-21.

[6] D. Giron, E. Huguet, G.N. Stone, M. Body, Insect-induced effects on plants and possible effectors used by galling and leaf-mining insects to manipulate their hostplant, J. Ins. Physiol. 84 (2016) 70-89.

[7] L.Q. Chen, SWEET sugar transporters for phloem transport and pathogen nutrition, New Phytol. 201 (2014) 1150-1155.

[8] J. Sandström, A. Telang, N.A. Moran, Nutritional enhancement of host plants by aphids - a comparison of three aphid species on grasses, J. Ins. Physiol. 46 (2000) $33-40$.

[9] M.G. Mitchum, R.S. Hussey, T.J. Baum, X. Wang, A.A. Elling, M. Wubben, E.L. Davis, Nematode effector proteins: an emerging paradigm of parasitism, New Phytol. 199 (2013) 879-894.

[10] P.N. Dodds, J.P. Rathjen, Plant immunity: towards an integrated view of plant-pathogen interactions, Nat. Rev. Genet. 11 (2010) 539.

[11] L. Lo Presti, D. Lanver, G. Schweizer, S. Tanaka, L. Liang, M. Tollot, A. Zuccaro, S. Reissmann, R. Kahmann, Fungal effectors and plant susceptibility, Ann. Rev. Plant Biol. 66 (2015) 513-545.

[12] M. Franceschetti, A. Maqbool, M.J. Jiménez-Dalmaroni, H.G. Pennington, S. Kamoun, M.J. Banfield, Effectors of filamentous plant pathogens: commonalities amid diversity, Microbiol. Mol. Biol. Rev. 81 (2017) e00066-16.

[13] I. Kaloshian, L.L. Walling, Hemipteran and dipteran pests: effectors and plant host immune regulators, J. Integr. Plant Biol. 58 (2016) 350-361.

[14] S. Basu, S. Varsani, J. Louis, Altering plant defenses: herbivore-associated molecular patterns and effector arsenal of chewing herbivores, Mol. Plant Microbe Interact. 31 (2017) 13-21.

[15] J.J. Stuart, M.S. Chen, R. Shukle, M.O. Harris, Gall midges (Hessian flies) as plant pathogens, Ann. Rev. Phytopathol. 50 (2012) 339-357.

[16] J. Stuart, Insect effectors and gene-for-gene interactions with host plants, Curr. Opin. Ins. Sci. 9 (2015) 56-61.

[17] D. Giron, G. Dubreuil, A. Bennett, F. Dedeine, M. Dicke, L.A. Dyer, M. Erb, M.O. Harris, E. Huguet, I. Kaloshian, A. Kawakita, C. Lopez-Vaamonde, T.M. Palmer, T. Petanidou, M. Poulsen, A. Sallé, J.-C. Simon, J. Terblanche, D. Thiery, N.K. Whiteman, H.A. Woods, S. Pincebourde, Promises and challenges in insect-plant interactions, Entomol. Exp. Appl. 166 (2017) (2018) 319-343.

[18] A. Sallé, S. Pointeau, S. Bankhead-Dronnet, C. Bastien, F. Lieutier, Unraveling the tripartite interactions among the woolly poplar aphid, its host tree, and their environment: a lead to improve the management of a major tree plantation pest? Ann. For. Sci. 74 (2017) 79.

[19] S. Pointeau, A. Ameline, F. Laurans, A. Sallé, Y. Rahbé, S. Bankhead-Dronnet, F. Lieutier, Exceptional plant penetration and feeding upon cortical parenchyma cells by the woolly poplar aphid, J. Ins. Physiol. 58 (2012) 857-866.

[20] F. Dardeau, E. Deprost, F. Laurans, V. Lainé, F. Lieutier, A. Sallé, Resistant poplar genotypes inhibit pseudogall formation by the wooly poplar aphid, Phloeomyzus passerinii Sign, Trees 28 (2014) 1007-1019.

[21] A. Sallé, R. Jerger, C. Vincent-Barbaroux, O. Baubet, D. Dahuron, S. Bourgerie, F. Lieutier, Tree-killing aphid dramatically reduces bark contents in carbohydrates and nitrogen compounds, For. Ecol. Manage. 407 (2018) 23-30.

[22] F. Dardeau, M. Body, A. Berthier, F. Miard, J.P. Christidès, M. Feinard-Duranceau, F. Brignolas, D. Giron, F. Lieutier, A. Sallé, Effects of fertilisation on amino acid mobilisation by a plant-manipulating insect, Ecol. Entomol. 40 (2015) 814-822.

[23] F. Dardeau, S. Pointeau, A. Ameline, F. Laurans, A. Cherqui, F. Lieutier, A. Sallé, Host manipulation by a herbivore optimizes its feeding behaviour, Anim. Behav. 95 (2014) 49-56.

[24] J.F. Tooker, A.M. Helms, Phytohormone dynamics associated with gall insects, and their potential role in the evolution of the gall-inducing habit, J. Chem. Ecol. 40 (2014) 742-753.

[25] N. Harmel, E. Létocart, A. Cherqui, P. Giordanengo, G. Mazzucchelli, 
F. Guillonneau, E. De Pauw, E. Haubruge, F. Francis, Identification of aphid salivary proteins: a proteomic investigation of Myzus persicae, Ins. Mol. Biol. 17 (2008) 165-174.

[26] M. De Vos, G. Jander, Myzus persicae (green peach aphid) salivary components induce defence responses in Arabidopsis thaliana, Plant Cell Environ. 32 (2009) $1548-1560$.

[27] Z. Ren, A.J. Harris, R.B. Dikow, E. Ma, Y. Zhong, J. Wen, Another look at the phylogenetic relationships and intercontinental biogeography of eastern Asian-north American Rhus gall aphids (Hemiptera: aphididae: eriosomatinae) evidence from mitogenome sequences via genome skimming, Mol. Phylogenet. Evol. 117 (2017) 102-110.

[28] A. Bishopp, S. El-Showk, D. Weijers, B. Scheres, J. Friml, E. Benková, A. Pekka Mähönen, Y. Helariutta, A mutually inhibitory interaction between auxin and cytokinin specifies vascular pattern in roots, Curr. Biol. 21 (2011) 917-926.

[29] T. Kiba, H. Yamada, T. Mizuno, Characterization of the ARR15 and ARR16 response regulators with special reference to the cytokinin signaling pathway mediated by the AHK4 histidine kinase in roots of Arabidopsis thaliana, Plant Cell Physiol. 43 (2002) 1059-1066.

[30] D. Zerbino, E. Birney, Velvet: algorithms for de novo short read assembly using de Bruijn graphs, Gen. Res. (2008) 074492.

[31] M.H. Schulz, D.R. Zerbino, M. Vingron, E. Birney, Oases: robust de novo RNA-seq assembly across the dynamic range of expression levels, Bioinformatics 28 (2012) 1086-1092.

[32] Y. Yang, S.A. Smith, Optimizing de novo assembly of short-read RNA-seq data for phylogenomics, BMC Genomics 14 (2013) 328.

[33] O. Nishimura, Y. Hara, S. Kuraku, Volante for standardizing completeness assessment of genome and transcriptome assemblies, Bioinformatics 33 (2017) 3635-3637.

[34] D. Hyatt, G.L. Chen, P.F. LoCascio, M.L. Land, F.W. Larimer, L.J. Hauser, Prodigal: prokaryotic gene recognition and translation initiation site identification, BMC Bioinformat. 11 (2010) 119.

[35] T.N. Petersen, S. Brunak, G. von Heijne, H. Nielsen, SignalP 4.0: discriminating signal peptides from transmembrane regions, Nat. Methods 8 (2011) 785.

[36] R. Ji, H. Yu, Q. Fu, H. Chen, W. Ye, S. Li, Y. Lou, Comparative transcriptome analysis of salivary glands of two populations of rice brown planthopper, Nilaparvata lugens, that differ in virulence, PLoS One 8 (2013) e79612.

[37] J.D. Bendtsen, L.J. Jensen, N. Blom, G. von Heijne, S. Brunak, Feature-based prediction of non-classical and leaderless protein secretion, Protein Eng. Des. Sel. 17 (2004) 349-356.

[38] O. Emanuelsson, H. Nielsen, S. Brunak, G. von Heijne, Predicting subcellular localization of proteins based on their N-terminal amino acid sequence, J. Mol. Biol. 300 (2000) 1005-1016.

[39] A. Pierleoni, P.L. Martelli, R. Casadio, PredGPI: a GPI-anchor predictor, BMC Bioinformat. 9 (2008) 392

[40] A. Conesa, S. Götz, J.M. García-Gómez, J. Terol, M. Talón, M. Robles, Blast2GO: a universal tool for annotation, visualization and analysis in functional genomics research, Bioinformat 21 (2005) 3674-3676.

[41] P. Jones, D. Binns, H.Y. Chang, M. Fraser, W. Li, C. McAnulla, H. McWilliam, J. Maslen, A. Mitchell, G. Nuka, S. Pesseat, A.F. Quinn, A. Sangrador-Vegas, M. Scheremetjew, S.-Y. Yong, R. Lopez, S. Hunter, InterProScan 5: genome-scale protein function classification, Bioinformat 30 (2014) 1236-1240.

[42] Y. Wang, D. Coleman-Derr, G. Chen, Y.Q. Gu, OrthoVenn: a web server for genome wide comparison and annotation of orthologous clusters across multiple species, Nucleic Acids Res. 43 (2015) W78-W84.

[43] S. Pundir, M.J. Martin, C. O’Donovan, Uniprot protein knowledgebase, in: C. Wu, C. Arighi, K. Ross (Eds.), Protein Bioinformatics. Methods in Molecular Biology, Vol 1558, Humana Press, New York, 2017, pp. 41-55.

[44] K. Guo, W. Wang, L. Luo, J. Chen, Y. Guo, F. Cui, Characterization of an aphidspecific, cysteine-rich protein enriched in salivary glands, Biophys. Chem. 189 (2014) 25-32.

[45] M. Jaouannet, P.A. Rodriguez, P. Thorpe, C.J.G. Lenoir, R. MacLeod, C. EscuderoMartinez, J.I.B. Bos, Plant immunity in plant-aphid interactions, Front. Plant Sci. 5 (2014) 663.

[46] Y. Pan, J. Zhu, L. Luo, L. Kang, F. Cui, High expression of a unique aphid protein in the salivary glands of Acyrthosiphon pisum, Physiol. Mol. Plant Pathol. 92 (2015) 175-180.

[47] D.A. Elzinga, G. Jander, The role of protein effectors in plant-aphid interactions, Curr. Opin. Plant Biol. 16 (2013) 451-456.

[48] A. Cherqui, W.F. Tjallingii, Salivary proteins of aphids, a pilot study on identification, separation and immunolocalisation, J. Ins. Physiol. 46 (2000) 1177-1186.

[49] J.L. Yang, R. Yang, A.C. Cheng, R.Y. Jia, M.S. Wang, S.H. Zhang, Five-minute purification of PCR products by new-freeze-squeeze method, J. Food Agric. Environ. 8 (2010) 32-33.

[50] M.E. Maffei, A. Mithöfer, W. Boland, Insects feeding on plants: rapid signals and responses preceding the induction of phytochemical release, Phytochemistry 68 (2007) 2946-2959.

[51] F.H. Wu, S.C. Shen, L.Y. Lee, S.H. Lee, M.T. Chan, C.S. Lin, Tape-Arabidopsis Sandwich-a simpler Arabidopsis protoplast isolation method, Plant Meth. 5 (2009) 16.

[52] J. Guo, J.L. Morrell-Falvey, J.L. Labbé, W. Muchero, U.C. Kalluri, G.A. Tuskan, J.G. Chen, Highly efficient isolation of Populus mesophyll protoplasts and its application in transient expression assays, PLoS One 7 (2012) e44908.

[53] S. Arvidsson, M. Kwasniewski, D.M. Riaño-Pachón, B. Mueller-Roeber,
QuantPrime-a flexible tool for reliable high-throughput primer design for quantitative PCR, BMC Bioinformat. 9 (2008) 465.

[54] Z. Tong, Z. Gao, F. Wang, J. Zhou, Z. Zhang, Selection of reliable reference genes for gene expression studies in peach using real-time PCR, BMC Mol. Biol. 10 (2009) 71.

[55] J.E. Malamy, P.N. Benfey, Organization and cell differentiation in lateral roots of Arabidopsis thaliana, Development 124 (1997) 33-44.

[56] R Core Team, R: a Language and Environment for Statistical Computing, R Foundation for Statistical Computing, Vienna, Austria, 2013 . http://www.Rproject.org/.

[57] R. Suzuki, H. Shimodaira, Pvclust: an R package for assessing the uncertainty in hierarchical clustering, Bioinformatics 22 (2006) 1540-1542.

[58] Y. Cuesta-Astroz, F.S. de Oliveira, L.A. Nahum, G. Oliveira, Helminth secretomes reflect different lifestyles and parasitized hosts, Int. J. Parasitol. 47 (2017) 529-544.

[59] S. Vandermoten, N. Harmel, G. Mazzucchelli, E. De Pauw, E. Haubruge, F. Francis, Comparative analyses of salivary proteins from three aphid species, Ins. Mol. Biol. 23 (2014) 67-77.

[60] W.R. Cooper, J.W. Dillwith, G.J. Puterka, Comparisons of salivary proteins from five aphid (Hemiptera: aphididae) species, Environ. Entomol. 40 (2011) 151-156.

[61] S.J. Nicholson, S.D. Hartson, G.J. Puterka, Proteomic analysis of secreted saliva from Russian Wheat Aphid (diuraphis noxia Kurd.) biotypes that differ in virulence to wheat, J. Proteomics 75 (2012) 2252-2268.

[62] D.A. Elzinga, G. Jander, The role of protein effectors in plant-aphid interactions, Curr. Opin. Plant Biol. 16 (2013) 451-456.

[63] S. Cambier, O. Ginis, S.J. Moreau, P. Gayral, J. Hearn, G. Stone, D. Giron, E. Huguet, J.M. Drezen, Gall wasp transcriptomes unravel potential effectors involved in molecular dialogues with oak and rose bushes, Front. Physiol. 10 (2019) 926.

[64] J.S. Ramsey, A.C.C. Wilson, M. de Vos, Q. Sun, C. Tamborindeguy, A. Winfield, G. Malloch, D.M. Smith, B. Fenton, S.M. Gray, G. Jander, Genomic resources for Myzus persicae: EST sequencing, SNP identification, and microarray design, BMC Genom. 8 (2007) 423

[65] H. Boulain, F. Legeai, E. Guy, S. Morlière, N.E. Douglas, J. Oh, M. Murugan, M. Smith, J. Jaquiéry, J. Peccoud, F.F. White, J.C. Carolan, J.-C. Simon, A. Sugio, Fast evolution and lineage-specific gene family expansions of aphid salivary effectors driven by interactions with host-plants, Genome Biol. Evol. 10 (2018) 1554-1572.

[66] J.C. Carolan, D. Caragea, K.T. Reardon, N.S. Mutti, N. Dittmer, K. Pappan, F. Cui, M. Castaneto, J. Poulain, C. Dossat, D. Tagu, J.C. Reese, G.R. Reeck, T.L. Wilkinson, O.R. Edwards, Predicted effector molecules in the salivary secretome of the pea aphid (Acyrthosiphon pisum): a dual transcriptomic/proteomic approach, J. Proteome Res. 10 (2011) 1505-1518.

[67] C. Testerink, T. Munnik, Phosphatidic acid: a multifunctional stress signaling lipid in plants, Trends Plant Sci. 10 (2005) 368-375.

[68] H.W. Xue, X. Chen, Y. Mei, Function and regulation of phospholipid signalling in plants, Biochem. J. 421 (2009) 145-156.

[69] E.O. Martinson, J.D. Hackett, C.A. Machado, A.E. Arnold, Metatranscriptome analysis of fig flowers provides insights into potential mechanisms for mutualism stability and gall induction, PLoS One 10 (2015) e0130745.

[70] I. Morkunas, V.C. Mai, B. Gabryś, Phytohormonal signaling in plant responses to aphid feeding, Acta Physiol. Plant. 33 (2011) 2057-2073.

[71] P.I. Kerchev, B. Fenton, C.H. Foyer, R.D. Hancock, Infestation of potato (Solanum tuberosum L.) by the peach-potato aphid (Myzus persicae Sulzer) alters cellular redox status and is influenced by ascorbate, Plant Cell Environ. 35 (2012) 430-440.

[72] J. Louis, J. Shah, Arabidopsis thaliana-myzus persicae interaction: shaping the understanding of plant defense against phloem-feeding aphids, Front. Plant Sci. 4 (2013) 213.

[73] B. Favery, M. Quentin, S. Jaubert-Possamai, P. Abad, Gall-forming root-knot nematodes hijack key plant cellular functions to induce multinucleate and hypertrophied feeding cells, J. Ins. Physiol. 84 (2016) 60-69.

[74] A. Mine, C. Seyfferth, B. Kracher, M.L. Berens, D. Becker, K. Tsuda, The defense phytohormone signaling network enables rapid, high-amplitude transcriptional reprogramming during effector-triggered immunity, Plant Cell 30 (2018) 1199-1219.

[75] L. Wu, H. Chen, C. Curtis, Z.Q. Fu, Go in for the kill: how plants deploy effectortriggered immunity to combat pathogens, Virulence 5 (2014) 710-721.

[76] K. Kazan, R. Lyons, Intervention of phytohormone pathways by pathogen effectors, Plant Cell 26 (2014) 2285-2309.

[77] J.E. Park, J.Y. Park, Y.S. Kim, P.E. Staswick, J. Jeon, J. Yun, S.-Y. Kim, J. Kim, Y.H. Lee, C.M. Park, GH3-mediated auxin homeostasis links growth regulation with stress adaptation response in Arabidopsis, J. Biol. Chem. 282 (2007) 10036-10046.

[78] B. Jones, S.A. Gunnerås, S.V. Petersson, P. Tarkowski, N. Graham, S. May, K. Dolezal, G. Sandberg, K. Ljung, Cytokinin regulation of auxin synthesis in Arabidopsis involves a homeostatic feedback loop regulated via auxin and cytokinin signal transduction, Plant Cell 22 (2010) 2956-2969.

[79] G.E. Schaller, A. Bishopp, J.J. Kieber, The yin-yang of hormones: cytokinin and auxin interactions in plant development, Plant Cell 27 (2015) 44-63.

[80] J.A. O'Brien, E. Benková, Cytokinin cross-talking during biotic and abiotic stress responses, Front. Plant Sci. 4 (2013) 451.

[81] A. Karczmarek, H. Overmars, J. Helder, A. Goverse, Feeding cell development by cyst and root-knot nematodes involves a similar early, local and transient activation of a specific auxin-inducible promoter element, Mol. Plant Pathol. 5 (2004) 343-346.

[82] F.L. Goggin, Plant-aphid interactions: molecular and ecological perspectives, Curr. Opin. Plant Biol. 10 (2007) 399-408. 